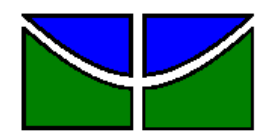

Universidade de Brasília

Faculdade de Economia, Administração, Contabilidade e Ciências da Informação e Documentação Departamento de Administração

IVONE MARIA DE SOUZA

RESPONSABILIDADE SOCIAL CORPORATIVA: Um olhar para as ações promovidas em ambiente corporativo voltada aos seus colaboradores

Brasília - DF 


\section{IVONE MARIA DE SOUZA}

\section{RESPONSABILIDADE SOCIAL CORPORATIVA: Um olhar para as ações promovidas em ambiente corporativo voltada aos seus colaboradores}

Projeto de monografia apresentado ao Departamento de Administração como requisito parcial à obtenção do título de Bacharel em Administração, na modalidade a distância, pela Universidade de Brasília (UnB).

Professor Orientador: MSc. Gemael Chaebo

Brasília - DF 


\title{
RESPONSABILIDADE SOCIAL CORPORATIVA: Um olhar para as ações promovidas em ambiente corporativo voltada aos seus colaboradores
}

\begin{abstract}
A Comissão Examinadora, abaixo identificada, aprova o Trabalho de Conclusão do Curso de Administração da Universidade de Brasília da aluna
\end{abstract}

Ivone Maria de Souza

MSc. Gemael Chaebo

Professor-Orientador

MSc. Wolney Resende

Professor-Examinador

Brasília, 03 de Dezembro de 2011 


\section{RESUMO}

O presente trabalho pretende identificar a percepção dos colaboradores de instituição financeira a respeito das práticas de Responsabilidade Social Corporativa (RSC) no âmbito interno da organização. O referencial teórico apresenta a RSC, práticas que as empresas propõem para o grupo de seus stakeholders, bem como propostas de discussão acerca da sua tangibilidade, sua veracidade e efetividade frente às situações que a RSC pretende mitigar. Para isso, utilizou-se metodologia qualitativa de coleta de dados, aplicando-se questionário e análise documental de dados, adotando o método de análise de conteúdo para o tratamento dos dados. Os principais resultados evidenciam um conhecimento a respeito da RSC pelos colaboradores e suas opiniões quanto à tangibilidade das ações que a empresa desenvolve, ressalta-se como aspecto negativo a falta de tempo para a prática das ações promovidas. A relevância do estudo se caracteriza pelo poder econômico que essas empresas exercem na sociedade, afetando a todos os quais com que se relaciona, sendo importante para a sociedade tornar evidentes suas práticas sociais. Diante desse fato é importante que novos estudos sejam realizados com o objetivo de analisar a coerência entre os discursos relacionados e as ações em sua prática. Palavras-chave: Bancos, Percepção colaboradores, Responsabilidade Social Corporativa. 


\section{SUMÁRIO}

1 INTRODUÇÃO

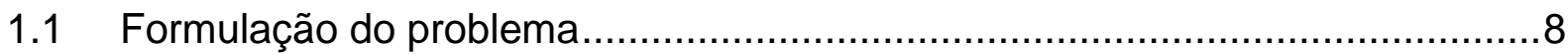

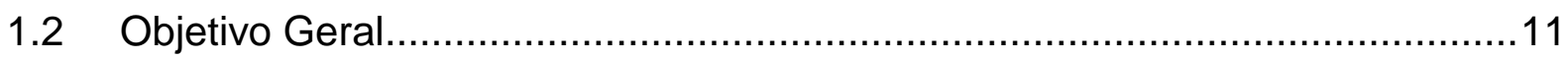

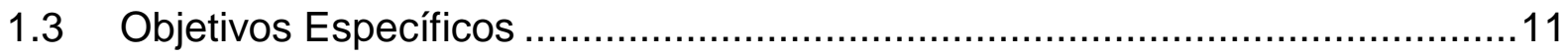

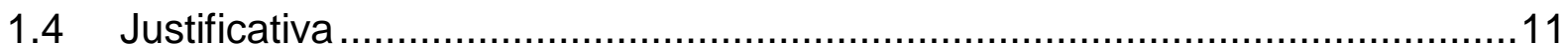

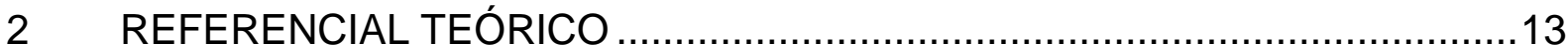

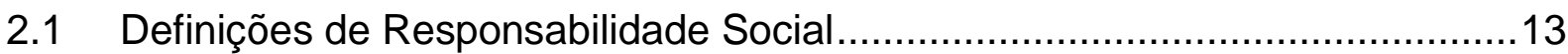

2.1.1 Fatos relevantes para a construção da Responsabilidade Social ....................14

2.1.2 A crise e a falência do Estado na gestão social .......................................17

2.1.3 O início das práticas sociais no Brasil e os principais indicadores ............19

2.1.4 A Responsabilidade Social utilizada como Marketing Social nas

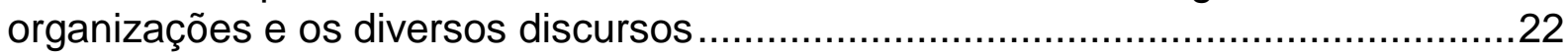

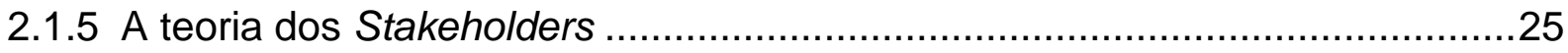

2.1.6 Os caminhos da responsabilidade social no Brasil......................................28

2.1.7 A responsabilidade social nas Instituições Financeiras ................................30

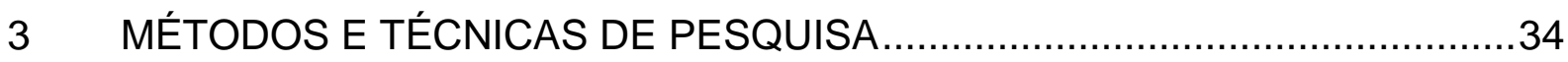

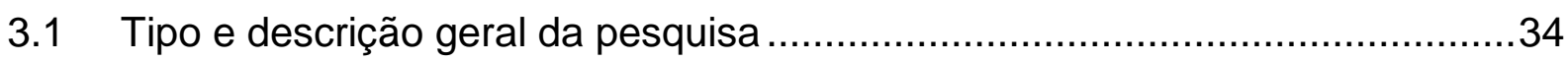

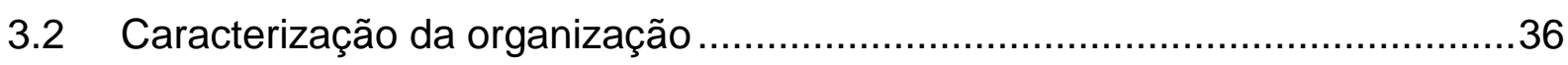

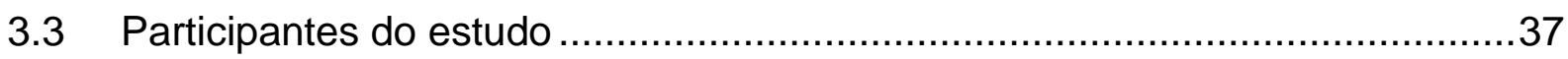

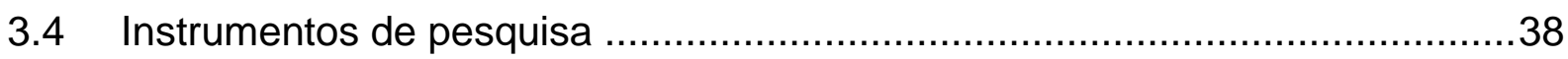

3.5 Procedimentos de coleta e de análise de dados ............................................39

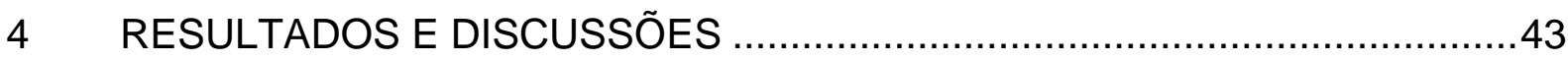

4.1 Práticas propostas no âmbito interno da corporação. .......................................43

4.2 Interação entre o discurso pronunciado pela empresa e as práticas

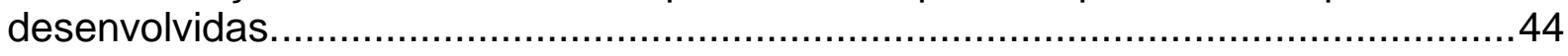

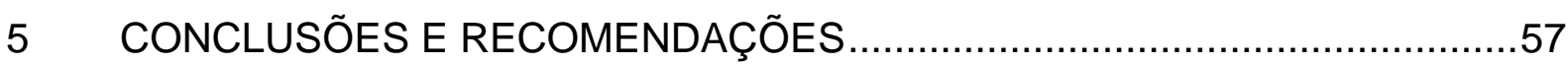

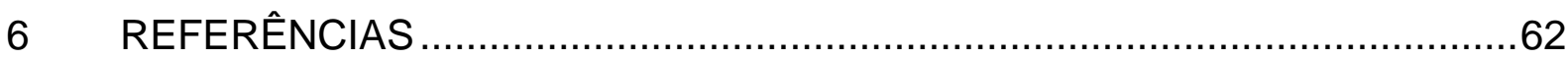

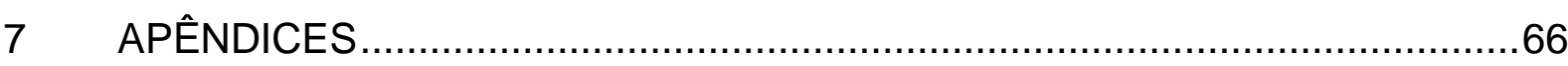




\section{INTRODUÇÃO}

O tema responsabilidade social vem ganhando maior espaço dentro das organizações nos últimos anos e também têm sido assunto recorrente nas principais notícias no mundo inteiro. Parece existir uma crescente preocupação por parte das empresas em se adequar às políticas de investimentos sociais.

Maximiano (2006) relata que o papel e o impacto social das organizações na sociedade se traduzem em tendências como a responsabilidade social da empresa, governança e cidadania corporativa. $O$ autor ainda descreve que o princípio da responsabilidade social se baseia na premissa de que as organizações são instituições sociais que existem com autorização da sociedade, dessa maneira utilizam-se de seus recursos e afetam sua qualidade de vida.

Drucker (1969, p. 236) ressalta a responsabilidade das organizações para com a qualidade de vida das pessoas, não sendo somente responsáveis pela venda de mercadorias, mas se trata de uma oportunidade dos administradores enxergarem alem de uma visão econômica. $O$ autor ainda destaca o desafio que é integrar o social e o econômico, mas ressalta também que pode se tratar de uma nova oportunidade.

Segundo Drucker (1989, apud KARKOTLI, 2006), não se pode afirmar que uma empresa tenha como único propósito o desenvolvimento econômico, mas esse por sua vez deve ser sua primeira responsabilidade. $O$ autor destaca que a empresa que não trabalha com ênfase em obter lucro é irresponsável, mas, ressalta que toda empresa deve assumir responsabilidade pelo impacto causado quanto aos empregados, o meio ambiente, os clientes, tudo e todos com que se relaciona.

Drucker (1976) entende que a questão principal não gira em torno de quais são as responsabilidades sociais da empresa, mas sim, quais os impactos que essas trazem para a sociedade em detrimento da sua função. $O$ autor ainda relaciona como sendo a primeira lei da responsabilidade social, o dever que as organizações têm de minimizar os impactos causados nas pessoas, tanto quanto possível. A segunda lei, colocando essa como a mais 
importante delas, seria de prever esse impacto. "Faz parte das atribuições da organização olhar para diante e procurar saber quais dos seus impactos terão probabilidades de se transformarem em problemas sociais" (DRUCKER, 1976, p. 231). Essas organizações têm de se aliar para satisfazer as necessidades e os desejos sociais, transformando-os em negócios lucrativos.

A discussão demonstra as dificuldades de sobrevivência para as empresas em uma sociedade miserável, falida e subdesenvolvida, pois, é dela que tira seu próprio desenvolvimento, comercializando seus produtos e serviços, estimulando a economia e afetando a qualidade de vida das pessoas.

Reforçando o pensamento de Drucker em transformar os problemas sociais em negócios lucrativos, Grabrielle (2008) destaca os benefícios que a empresa pode obter aliando as estratégias da empresa às práticas de responsabilidade social, conquistando mais do que meramente marketing institucional, gerando maior satisfação entre seus colaboradores, fidelizando seus clientes e consolidando uma imagem positiva junto a todo o grupo de envolvidos, além de contribuir para a preservação do meio ambiente e para o desenvolvimento das gerações futuras.

Podemos observar alguns fatores importantes ao aumento da adesão das empresas brasileiras às políticas sociais. Dentre eles destaca-se a crise econômica que assolou o país nos anos 80 , aumentou o desemprego e a pobreza, levando o Estado a reduzir os investimentos sociais. Isso obrigou as empresas a incorporar em suas estratégias organizacionais a preocupação para com o desenvolvimento da sociedade, o que deixou de ser responsabilidade única e exclusiva do Estado.

Nesse sentido, Parente (2006) entende que incorporar uma cultura organizacional socialmente responsável não significa assumir as atribuições do Estado, mas sim incorporar um novo regime de desenvolvimento econômico e social.

Dessa forma, políticas e diretrizes não podem estar somente voltadas para o lucro financeiro, sendo necessário pensar no futuro de gerações que possam contribuir para o desenvolvimento do país, bem como aliar as práticas e estratégias para o interesse de todos que são influenciados por esta.

Em pesquisa realizada pelo IPEA (Instituto de Pesquisa Econômica Aplicada) divulgada em (2006) as empresas brasileiras têm avançado nessa 
questão. $O$ resultado final da pesquisa Ação Social das Empresas realizada pela segunda vez em todo o Brasil, aponta para uma maior adesão entre as empresas participantes que aderiram a ações sociais em prol da comunidade. Entre o período de 2000 a 2004 o percentual de participação evoluiu de 59\% para $69 \%$, sendo aproximadamente 600 mil empresas atuando voluntariamente.

Obtendo uma imagem de responsabilidade socioambiental perante a sociedade como um todo, essas empresas procuram divulgar com a maior ênfase possível as suas práticas desenvolvidas. Basta observar o apelo constante de importantes instituições financeiras junto à mídia quando procuram transmitir a ideia de que seus produtos e serviços promovem o bemestar social e o desenvolvimento econômico.

O objeto de estudo desse trabalho é voltado para as ações de responsabilidade corporativa desenvolvidas pelo Banco $X^{1}$. A pesquisa se propõe a identificar junto aos colaboradores, que ocupam cargos não comissionados, das Agências do Banco $\mathrm{X}$, das cidades de Ji-Paraná, Ariquemes, Cacoal e Vilhena, localizadas no estado de Rondônia $(R O)$, região norte do país, qual a percepção que os mesmos têm dessas ações, qual o seu nível de conhecimento, sua participação e envolvimento nas ações que a organização se propõe a promover no âmbito interno. Ainda, quais os aspectos são considerados positivos e negativos pelo público pesquisado.

\subsection{Formulação do problema}

Karkotli (2006) propõe diversas definições da área social que se referem à Responsabilidade Social, descrevendo cada uma delas. Dentre tais definições é interessante esclarecer o conceito ao qual esse trabalho tem por objetivo delimitar sua pesquisa - Responsabilidade Social Corporativa (RSC).

Segundo Karkotli (2006), as empresas são pressionadas por agentes internos e externos a adotarem práticas de responsabilidade social, levando em

\footnotetext{
${ }^{1}$ Banco $X$ - é uma instituição financeira nacional que não autoriza a divulgação da razão social. Assim será adotado nesse estudo este nome fictício para preservar o sigilo da instituição.
} 
conta os aspectos sociais, éticos, além dos econômico-financeiros. Esses agentes são denominados stakeholders, que são todo e qualquer grupo de indivíduos que é afetado ou que afeta o alcance dos objetivos da empresa. Ou seja, todos aos quais interessa as atividades desenvolvidas pela empresa, seus acionistas, clientes, funcionários e colaboradores, governo, comunidade local, dentre outros.

Por meio desse conceito as organizações desenvolvem a RSC, definida por Karkotli (2006, p. 63), como:

[...] o comportamento ético e responsável em busca de qualidade nas relações que a organização estabelece com todos os seus stakeholders, associado direta e indiretamente ao negócio da empresa, incorporado à orientação estratégica da empresa e refletido em desafios éticos para as dimensões econômicas, ambiental e social.

Como pode-se observar, responsabilidade social não incorpora somente as ações que uma organização desenvolve com o objetivo de beneficiar a comunidade externa na qual está inserida, nem somente para com seus acionistas e governo. Nem apenas para desenvolver produtos e serviços com apelo ecológico, mas implica em responsabilidade também para com seus colaboradores diretos, com sua qualidade de vida, seu desenvolvimento e crescimento profissional, sua saúde e segurança no trabalho, ascensão profissional, dentre outros aspectos.

O Instituto Ethos de Responsabilidade Social Empresarial, organização que atua na área social desde 1998, divulga os indicadores Ethos, que relaciona diretrizes que as organizações podem incorporar em suas políticas com relação ao meio ambiente, valores e transparência, para com seus fornecedores, público interno, consumidores, comunidade, governo e sociedade. Nos indicadores relacionados ao público interno (2011) estão:

[...] relacionamento com sindicatos, gestão participativa, participação nos lucros e resultados, compromisso com o futuro das crianças, valorização da diversidade, comportamento frente a demissões, compromisso com o desenvolvimento profissional e empregabilidade, cuidados com saúde, segurança e condições de trabalho, além de preparação para aposentadoria. 
A instituição financeira selecionada para o estudo faz menção ao Instituto Ethos em sua página na internet, destacando:

Segundo o Instituto Ethos de Responsabilidade Social Empresarial, a empresa socialmente responsável é aquela que possui a capacidade de ouvir os interesses das diferentes partes (acionistas, funcionários, prestadores de serviço, fornecedores, consumidores, comunidade, governo e meioambiente) e de conseguir incorporá-los no planejamento de suas atividades, buscando considerar as demandas de todos e não apenas dos acionistas ou proprietários.

A empresa se propõe a relacionar seus compromissos junto aos seus stakeholders, com base em tais indicadores, salientando que suas ações vão além do que é exigido pela Lei.

De acordo com Srour (2004, apud SOARES, 1998 p. 293), "[...] as relações que amarram empresa e contrapartes são relações de poder". Segundo o autor, as empresas desenvolvem ações de responsabilidade social e não somente pensam em maximizar seus lucros devido ao receio de que seus stakeholders possam retaliar a empresa, propagando uma imagem negativa e prejudicando sua condição econômica.

Farias (2004, apud SOARES, 2001, p. 1) faz menção a um discurso a respeito de "[...] uma certa ética e uma ação que não lhe corresponde", de forma que se pode questionar em que medida as ações propostas pela RSC correspondem à prática organizacional.

Nesse contexto entre discursos e práticas, propõe-se desenvolver uma pesquisa junto aos colaboradores do Banco $X$, que ocupam cargos não comissionados, das Agências das cidades de Ji-Paraná, Ariquemes, Cacoal e Vilhena, localizadas no estado de $\mathrm{RO}$, região norte do país, tendo como problemática a seguinte questão: Qual a percepção dos trabalhadores nãocomissionados sobre as ações de RSC do banco, observando seu conhecimento, participação e envolvimento? Ainda, quais os aspectos são considerados positivos ou negativos pelo público pesquisado? 


\subsection{Objetivo Geral}

O objetivo geral desse trabalho é identificar a percepção que os funcionários não-comissionados, das Agências do Banco X, das cidades de JiParaná, Ariquemes, Cacoal e Vilhena $(\mathrm{RO})$, têm em relação às práticas de RSC desenvolvidas em seu ambiente de trabalho.

\subsection{Objetivos Específicos}

Os objetivos específicos a que essa pesquisa se propõe são:

a) Identificar o conhecimento das ações de RSC realizadas pelo banco;

b) Identificar a participação e o envolvimento nas ações de RSC propostas pelo banco;

c) Evidenciar os aspectos positivos e negativos considerados pelos colaboradores.

\subsection{Justificativa}

A discussão proposta em relação ao tema nos mostra a influência que as empresas exercem na sociedade, tanto no aspecto econômico quanto no político. Elas utilizam de todos os recursos possíveis para promover sua expansão econômica. Para Drucker (1969), ao assumir o seu impacto junto aos grupos afetados, as empresas devolvem parte dos recursos humanos, naturais e financeiros utilizados.

As exigências por parte dos stakeholders têm feito com que as empresas percebam a necessidade e a viabilidade de aliar as suas estratégias temas como ética e responsabilidade social. Segundo Karkotli (2006), as empresas precisam aprender a aliar lucros, cumprir a lei, além de ter um comportamento ético e socialmente responsável. De acordo com o autor, (2006, p. 130): 
O capitalismo selvagem ensinou que ética e lucro são conceitos incompatíveis. O mundo, no entanto, mudou e a economia globalizada tem demonstrado que a ética pode ser um elemento de valorização da empresa.

As empresas que não se adequarem para obter vantagem econômica aliada à responsabilidade social são suicidas. $O$ desafio da mudança é gritante a todos os envolvidos que caminham para a construção de uma "cadeia responsável", onde a exigência de atitudes pautadas em ética e responsabilidade social é cobrada por todos (KARKOTLI, 2006).

Nesse contexto, a RSC engloba a preocupação com o desenvolvimento do próprio corpo organizacional, a sua equipe de trabalho, pois, para alcançar bons resultados é preciso que essa esteja motivada, alinhada com as estratégias da empresa, acompanhando o seu desenvolvimento, se atualizando, procurando seu próprio crescimento e seu desenvolvimento profissional, que se sinta segura e tenha qualidade de vida.

Espera-se que essa pesquisa promova subsídios para a tomada de decisão por parte dos empresários, gerentes e administradores do banco, a respeito das práticas de RSC em uso e como elas podem contribuir para o desenvolvimento da organização alinhada à sociedade. Pretende-se também, estimular o aumento de pesquisas acadêmicas a respeito das práticas de RSC desenvolvidas em instituições bancárias brasileiras. 


\section{REFERENCIAL TEÓRICO}

Este capítulo tem por objetivo fazer uma revisão da literatura a respeito de Responsabilidade Social Corporativa (RSC), evidenciando desde os conceitos iniciais até sua evolução mais recente, ainda, a relação existente entre as práticas sociais $\mathrm{e}$ as estratégias organizacionais, além do compromisso econômico e social para com seus stakeholders. Dessa forma, é necessário elencar as principais orientações, normas e códigos regulamentadores no campo da Responsabilidade Social e o início da atuação brasileira. Para tanto, os seguintes tópicos serão abordados:

$\checkmark$ Definições de Responsabilidade Social;

$\checkmark$ Fatos Relevantes para a construção da Responsabilidade Social;

$\checkmark$ A crise e a falência do Estado na gestão social;

$\checkmark$ O início das práticas sociais no Brasil e os principais indicadores;

$\checkmark$ A Responsabilidade Social utilizada como marketing social nas organizações e os diversos discursos;

$\checkmark$ A teoria dos Stakeholders;

$\checkmark$ Os caminhos da Responsabilidade Social no Brasil;

$\checkmark$ A Responsabilidade Social nas Instituições Financeiras.

\subsection{Definições de Responsabilidade Social}

De acordo com Ashley (2004), existem vários conceitos que são atribuídos a responsabilidade social. A autora relata que para muitos representa a ideia de filantropia ou ações caridosas, outros a vêem como um comportamento ético, outros ainda a entendem como uma resposta ao impacto causado à sociedade na forma de uma obrigação legal, para alguns, pode ser associada à ideia de função social, dentre outros. 
Ashley (2004) a define como o compromisso que as empresas devem ter para com a sociedade como um todo, assumindo todas as suas obrigações, agindo de forma moralmente correta, além de atender as obrigações legais, visando um desenvolvimento autossustentável, praticando ações que possam contribuir para uma melhor qualidade de vida da sociedade.

De acordo com Bowen (1953, apud ASHLEY, 2004, p. 6), a responsabilidade social é definida como: "[...] a obrigação do homem de negócios de adotar orientações, tomar decisões e seguir linhas de ação que sejam compatíveis com os fins e valores da sociedade". De acordo com o Instituto Ethos:

Responsabilidade social empresarial é a forma de gestão que se define pela relação ética e transparente da empresa com todos os públicos com os quais ela se relaciona e pelo estabelecimento de metas empresariais que impulsionem 0 desenvolvimento sustentável da sociedade, preservando recursos ambientais e culturais para as gerações futuras, respeitando a diversidade e promovendo a redução das desigualdades sociais.

Os pensamentos e discursos relacionados ao tema, leva ao entendimento de que as responsabilidades das empresas vão muito além do que compromisso com seu crescimento econômico e maximização de suas receitas. Mas, praticar responsabilidade social é uma forma de gestão orientada pela ética, que vai garantir um crescimento de maneira socialmente justa e economicamente viável, ainda autossustentável, além de assumir as implicações de seu impacto na sociedade.

\subsubsection{Fatos relevantes para a construção da Responsabilidade Social}

A literatura a respeito da responsabilidade social destaca um momento marcante da história como um dos aspectos que deram início a uma maior preocupação com os problemas sociais, a Revolução Industrial. 
Diversos autores como Ashley (2004), Souza (2008), Karkotli (2006), Roman (2004) e Parente (2006), concordam que os problemas sociais se agravaram com a expansão econômica dando início a discussão relacionada à gestão social nas empresas.

Souza (2008) descreve a grande influência da Revolução Industrial nas discussões relacionadas à gestão social. Para o autor, por um lado houve grande crescimento econômico, desenvolvimento das indústrias, avanço tecnológico, mas por outro, o uso indiscriminado dos recursos naturais e a expansão social e econômica deram origem aos problemas sociais e ambientais hoje amplamente discutidos.

O autor ainda relata que as primeiras contribuições a cerca da discussão da gestão social se deu em plena Revolução Industrial (1750-1850) e Revolução Francesa (1789-1799), com a intervenção dos socialistas utópicos, que discutiam e propunham mudanças no meio empresarial, defendendo os interesses da classe operária, combatendo a exploração da mão-de-obra, defendendo a criação de organizações alternativas, dentre outras atuações.

O autor destaca um dos socialistas utópicos, Robert Owen (1771-1858), como o pai da responsabilidade social, com grandes contribuições ao tema. Owen era empresário e diante das próprias dificuldades encontradas dentro do seu ambiente organizacional optou por aliar suas adversidades a outros desafios, investindo em equipamentos e benefícios sociais para a melhoria da qualidade de vida dos seus trabalhadores. Owen, ainda discursava junto ao governo para que o Estado pudesse intervir na economia, regulamentando as condições de trabalho da classe operária.

Souza e Oliveira (2006, apud SOUZA, 2008) descrevem as iniciativas sociais que Owen liderou. Dentre as suas muitas ideias estão filantropia e caridade, controle do trabalho infantil, urbanização e atenção à saúde coletiva, sistemas nacionais de emprego e educação, lazer e descanso semanal aos trabalhadores, política pública de combate à miséria e proteção ao trabalhador.

As contribuições de Owen evidenciam que, já naquela época, existiam defensores de uma atuação empresarial pautada na gestão social. Owen, mesmo na posição de empresário tinha capacidade de enxergar as mazelas sociais como um problema que afetaria a todos e que cabia não somente ao 
Estado, mas também às empresas assumir sua parcela de responsabilidade junto à sociedade.

Segundo Ashley (2004), até o início do século XX a premissa fundamental de toda e qualquer organização era a de gerar lucro para seus acionistas.

A autora relata um fato interessante ocorrido em 1919, nos EUA, o caso Dodge versus Ford, quando Henry Ford, presidente e acionista majoritário da empresa, tomou decisões que contrariavam os interesses dos acionistas John e Horace Dodge. Alegando objetivos sociais, ele reverteu parte dos dividendos na capacidade de produção, aumento de salários e fundo de reserva para a redução esperada de receitas em função do corte nos preços dos carros. $\mathrm{O}$ caso correu favorável aos Dodges, com a justificativa que a empresa existe para o benefício e interesse de seus acionistas, ainda, que diretores tenham livre arbítrio apenas para tomar decisões que possam alcançar tal fim, não sendo permitido usar os lucros para outros investimentos que visem qualquer situação contrária a maximizar a receita de seus acionistas.

A autora ainda descreve outro caso, ocorrido em 1953, que retomaram as discussões a respeito de responsabilidade social. $O$ caso $A$. P. Smith Manufacturing Company versus Barlow. Nesse caso a decisão foi favorável às iniciativas sociais, dando ênfase às responsabilidades da empresa para com a sociedade, com a destinação de recursos para a Universidade de Princeton, dessa vez contrariando a parte dos acionistas.

Desde então, o tema vem evoluindo e ganhando espaço nas discussões acadêmicas e no meio empresarial. Assim também como os problemas sociais, que foram aumentando frente ao desemprego, pobreza, crises econômicas, entre outros aspectos.

Seguindo o pensamento de que as organizações existem para maximizar a receita de seus investidores, a discussão ganhou opiniões contrárias quanto à responsabilidade das empresas.

Segundo Jones (1996, apud ASHLEY, 2004, p. 21), alguns autores seguem uma linha de pensamento de Friedman, que salienta que os responsáveis pela direção da empresa somente devem tomar decisões que preservem os interesses dos acionistas, sempre com o objetivo de maximizar lucros. O autor ainda menciona a linha de pensamento do autor Leavitt, que se 
opõe a responsabilidade social nas empresas. Para ele as funções necessárias ao cumprimento da RSC são de responsabilidade de outras organizações, como governo, igrejas, sindicatos e organizações sem fins lucrativos.

De acordo com Ashley (2004), os argumentos a favor partem de autores que se enquadram em duas linhas de pensamento: ética e instrumental. Conforme a autora descreve, seguindo a linha ética, a RSC vem dos princípios religiosos e das normas sociais, envolvendo questões como agir de forma socialmente justa e moralmente correta. A outra linha instrumental aborda os benefícios em se aliar as práticas sociais ao desempenho econômico da empresa.

Diante das contribuições de diversos autores, podemos salientar o quanto se faz importante as reflexões a cerca das responsabilidades atribuídas ao meio empresarial e o posicionamento das empresas quanto a sua gestão empresarial, práticas e compromissos assumidos perante a sociedade.

\subsubsection{A crise e a falência do Estado na gestão social}

Para Roman (2004), após a segunda guerra mundial, permeou uma era de ouro do capitalismo, a economia estava em crescimento, havia produtividade, emprego e crescimento da renda per capita.

Segundo o autor, existia o chamado "Estado de Bem Estar Social" (wellfare state), que controlava as crises econômicas e comandava 0 desenvolvimento. $\mathrm{O}$ autor relata que a responsabilidade social era assumida $\mathrm{e}$ desempenhada pelo Estado. Mas durou pouco. Segundo o autor, a crise do petróleo em 1973, seguida pela onda inflacionária, dentre outros acontecimentos, deram origem a uma crise no Estado de Bem-Estar Social.

Souza (2008) menciona que as crises do petróleo e de acumulação de capital que se formaram nos anos 1970, no mundo capitalista, conduziram profundas mudanças na gestão empresarial, social e na gestão pública.

Segundo Roman (2004) e Souza (2008) com a crise do Estado de Bem Estar Social como principal mantedor dos serviços públicos que garantiam 
benefícios a população, se fez necessário uma reorganização das atribuições do Estado.

Podemos observar que esses fatores desencadearam uma série de ações por parte do Estado para que fosse possível prover os serviços públicos necessários à população. Observamos desde os anos 1980, que o Brasil passou por algumas transformações e reformas no Estado.

Souza (2008) destaca as grandes mudanças no Estado desde então. O autor da ênfase as ações do então presidente Fernando Collor de Melo que tomou medidas quanto ao enxugamento da máquina pública com demissões de elevado número de funcionários públicos e a extinção de órgãos, ainda, Itamar Franco que promoveu certa estabilidade econômica no país com a criação do plano real e outros. Até recentemente a gestão do ex-presidente Lula que promovia a presença do Estado na vida social com a criação de programas como Bolsa Família, as políticas de acesso ao ensino superior, inclusão digital, dentre outros.

A falta de recursos do Estado fez com que esse se reorganizasse de forma a partilhar suas obrigações, passando a incorporar esse novo cenário 0 meio empresarial, as organizações alternativas, todos assumindo sua parcela de responsabilidade perante a sociedade. De acordo com Parente (2006, p. 19):

A responsabilidade social engloba todos os setores da
sociedade: o primeiro setor, representado pelo governo; o
segundo setor, constituído pelas empresas; e o terceiro setor,
composto pelas instituições sociais, as ONGs e a sociedade.
Contudo é no setor empresarial que esta fundamentada a
possibilidade de mobilização para a mudança, em razão do
poder econômico que as empresas concentram e da
capacidade que têm de estimular seus colaboradores e
parceiros a contribuírem para a melhoria da sociedade.

O autor ainda chama a atenção para uma nova consciência da classe privilegiada da população, pois a pobreza e a miséria aceleram o crescimento da violência, afetando sua própria segurança.

Podemos observar que os problemas sociais já visíveis para Owen, ainda no período da Revolução Industrial, não puderam ficar escondidos: a crise do Estado, o aumento da população, a crise do desemprego, tudo desencadeou em problemas sociais que, quer queira quer não, afetam todo o país desde a 
sociedade mais rica até a mais pobre assolando de maneira mais evidente os mais pobres e miseráveis.

\subsubsection{O início das práticas sociais no Brasil e os principais indicadores}

Com a crise econômica assolando o País nos anos 1980, o Brasil começa a prover algumas iniciativas.

O site Brasil Cultura em sua página na internet destaca como um dos pioneiros o sociólogo Herbert de Souza (Betinho), que em 1979 fundou o IBASE - Instituto Brasileiro de Análises Sociais e Econômicas. Em 1993 organizou uma entidade governamental, o Conselho Nacional de Segurança Alimentar, e uma não-governamental, a Ação da Cidadania Contra a Miséria e pela Vida.

Cresce o número de organizações sem fins lucrativos, associações, sindicatos, entidades filantrópicas e também a pressão por parte da sociedade para atitudes pautadas na ética e no compromisso para com o bem estar social.

Segundo Ashley (2004), as primeiras discussões a respeito do tema surgiram em meados dos anos 1970, tendo como principal agente a Associação dos Dirigentes Cristãos de Empresa (ADCE). De acordo com a autora, a associação é uma entidade de empresários cristãos que pautam suas atividades empresariais e promoviam debates na época a respeito do balanço social com base nos princípios e doutrinas da igreja cristã.

Para Amoroso (2003, apud SANTOS, 2006, p. 72), as práticas brasileiras tornaram-se mais enfáticas a partir dos anos 1990. O autor destaca a criação de organizações como o GIFE - Grupo de Instituições, Fundações e Empresa, e do Instituto ETHOS de Empresas e Responsabilidade Social, além do lançamento do prêmio ECO de Cidadania Empresarial e ainda a criação do Selo do Balanço Social pelo sociólogo Herbert de Souza (Betinho).

Souza (2008) destaca o Instituto Ethos e seus indicadores de gestão social como referência mundial no âmbito da responsabilidade social. $\mathrm{O}$ autor ainda menciona a fundação da OSCIP - Instituto Brasileiro de Ética 
Concorrencial, em 2003, uma organização da sociedade civil de interesse público que têm por objetivo promover práticas empresariais pautadas pela ética, visando extinguir a evasão fiscal, falsificação, informalidade, dentre outros aspectos.

Como forma de regulamentar e orientar a adoção das práticas sociais pelas organizações surgiu vários indicadores, selos (certificações), normas de conduta, dentre outros.

Souza (2008) descreve como indicadores brasileiros o Balanço Social e a NBR $16001^{2}$ - Responsabilidade Social - Sistema de Gestão - Requisitos. A autora ainda menciona a SA $8000^{3}$ e a ISO $26000^{4}$ utilizadas mundialmente.

De acordo com Souza (2008), o Balanço Social foi popularizado pelo IBASE, como vimos acima, instituto fundado por Betinho. Desde 1998, o IBASE lançou o Selo Balanço Social Ibase/Betinho, com o intuito de estimular a participação das empresas na elaboração do Balanço Social. De acordo com o autor, as empresas que se propõe a divulgar o Balanço Social dentro dos critérios sugeridos pelo IBASE recebem o selo e por meio dele divulgam em suas embalagens, sites, campanhas publicitárias, entre outros meios, que investem recursos na responsabilidade social.

A NBR 16001, segundo Souza (2008), produzida pela Associação Brasileira de Normas Técnicas (ABNT), estabelece os requisitos mínimos para que uma empresa possa desenvolver um sistema de gestão da responsabilidade social. $\mathrm{O}$ autor enfatiza que se trata de um instrumento de orientação e que a sua adoção não significa que a empresa efetivamente desenvolva práticas sociais. A norma segue a metodologia PDCA (Plan-DoChek-Act), que se traduz para o português como planejar, fazer, verificar e atuar.

Quanto à norma SA 8000, o autor menciona que um de seus principais objetivos está na prevenção e não nas práticas, a norma fundamenta-se na preocupação de que as empresas não sejam acusadas de não atenderem a requisitos considerados éticos e socialmente justos. De acordo com Xavier e

\footnotetext{
${ }^{2}$ NBR 16001 - Norma produzida pela Associação Brasileira de Normas Técnicas (ABNT), como instrumento orientador para os processos de gestão da responsabilidade social.

${ }^{3}$ SA 8000 - Norma que estabelece orientações para a implementação de atuação das empresas pautadas pela responsabilidade social.

${ }^{4}$ ISO 26000 - Guia de diretrizes, não se constitui norma e nem emite certificados, atua como orientador das práticas de responsabilidade social.
} 
Souza (2004, apud SOUZA, 2008, p. 167), a norma aborda aspectos como: "trabalho infantil, trabalho forçado, saúde e segurança, discriminação, horário de trabalho, remuneração, entre outros".

De acordo com Costa (2011, p. 18), em 1 de Novembro de 2010, foi divulgada a Norma Internacional de Responsabilidade Social ( ISO 26000), que segundo o autor:

[...] fornece orientações para todos os tipos de organizações, independentemente do porte ou localização, sobre conceitos, termos e definições referentes à responsabilidade social; histórico, tendências e características da responsabilidade social; princípios e práticas relativas à responsabilidade social; os temas centrais e as questões referentes à responsabilidade social; integração, implementação e promoção de comportamento socialmente responsável em toda a organização e por meio de suas políticas e práticas dentro de sua esfera de influência; identificação e engajamento de partes interessadas; e comunicação de compromissos, desempenho e outras informações referentes à responsabilidade social.

Apesar da discussão efetiva a respeito da adoção de práticas sociais, ainda é pequeno o número de empresas e organizações certificadas. De acordo com Costa (2011, p. 18):

Em outubro de 2007, foi certificada a primeira empresa dentro do Programa Brasileiro de Certificação em Responsabilidade Social. Hoje, há 25 organizações certificadas na ABNT NBR 16001 e estima-se que estas organizações tenham incluído 110 localidades distintas e envolvido cerca de 8.100 trabalhadores, entre funcionários e subcontratados. Atualmente, existem cerca de 10 organizações em processo de implantação da ABNT NBR 16001, com possibilidade de serem certificadas até meados de 2011.

Segundo Souza (2008), a ISO 26000 não certificará, apenas servirá de um guia internacional para o tema de RSC. O autor ainda comenta uma discussão existente a respeito da concessão ou não de certificados por meio de normas legais e questiona se isso será positivo ou não para a responsabilidade social. De acordo com $\mathrm{o}$ autor, muitas empresas $\mathrm{e}$ organizações cometem fraudes, maquiando o meio empresarial com o intuito de conseguir selos e certificações que possam ser utilizados para agregar valor a sua imagem perante seus consumidores. Muitos acreditam que os guias de 
orientação são mais saudáveis, mas ainda há aqueles que mesmo estando sujeito a desvios, acreditam que a emissão de certificados forma um parâmetro para a responsabilidade social.

No que diz respeito à exigibilidade legal, por meio de normas e regulamentos, o que se percebe é que o pensamento empresarial tem que ser consciente. De nada servirão normas, certificações e guias se realmente não existir um comprometimento moral e ético no meio empresarial.

Os problemas sociais existentes já mostraram que não são parte exclusiva de uma única parcela da sociedade e que se atitudes não forem tomadas o futuro das empresas estará comprometido.

\subsubsection{A Responsabilidade Social utilizada como Marketing Social nas organizações e os diversos discursos}

As transformações políticas, o crescimento da economia e a competitividade entre as empresas provocaram profundas mudanças em seus sistemas de gestão sendo determinantes na adequação de suas estratégias, a implementação de ações de práticas sustentáveis.

De acordo com Parente (2006), a crescente globalização, a competitividade entre as empresas e o avanço da tecnologia, desencadeou um crescimento econômico nunca antes mensurado, no entanto, os problemas da humanidade se acentuaram. Segundo o autor, as empresas começaram a se dar conta da necessidade de adotar uma postura que pudesse promover o crescimento econômico aliado ao desenvolvimento sustentável.

O autor salienta que aliar um comportamento ético com atitudes socialmente responsáveis se tornou uma forma de agregar valor à empresa, construindo uma imagem favorável e gerando diferencial competitivo.

Aliar as práticas sociais da empresa ao então denominado marketing social passou a ter diversos discursos, sendo que alguns autores à reconhecem como diferencial competitivo e outros fazem críticas a possibilidade de que as empresas estejam utilizando a RSC somente como marketing visando agregar uma imagem positiva ao seu produto ou serviço, tendo como único objetivo final o lucro. 
Soares (2004) critica as práticas de responsabilidade social, relacionandoas puramente a estratégia de marketing ou adesão por parte das empresas a um atual modismo na busca por vantagem competitiva no mercado.

A autora fundamenta sua opinião em autores como Srour (1998, apud SOARES, 2004), que relaciona as práticas sociais das organizações como meio de garantir sua sobrevivência no âmbito empresarial, devido à crescente competitividade e a globalização. Garay (2001, apud SOARES, 2004) descreve esse novo modelo de gestão social como uma estratégia de marketing que tem como principal objetivo obter vantagem competitiva, agregar valor aos produtos e serviços ofertados e construir uma imagem positiva perante a sociedade.

A autora ainda salienta que as empresas não levam em consideração o sofrimento humano causado pelo trabalho e destaca as afirmações do autor Dejours (2001, apud SOARES, 2004), a respeito dos medos que se instalam no meio organizacional, como medo da incompetência, falta de reconhecimento, medo do desemprego, pressão por altos índices de produtividade e o rígido controle gerencial, além de levantar outros aspectos, tais como assédio sexual e moral.

Alguns autores como Credício (2003, apud SANTOS, 2005), não criticam a divulgação das práticas sociais das organizações, nem o fato de que por meio desse marketing social elas agreguem vantagem competitiva, mas o autor reforça uma discussão que esse diferencial tem que ser acompanhado de ética e discursos verdadeiros.

O autor ainda enfatiza que as próprias organizações já sentem as pressões por parte da sociedade para o desenvolvimento de ações sociais e que já não podem contar simplesmente com a qualidade de seus produtos como forma de sobrevivência, já que para o autor, qualidade é uma exigência natural e não um diferencial.

Nesse sentindo, Parente (2006) menciona que a pressão por parte da sociedade tem a crescer cada vez mais, fazendo com que não somente os seus clientes, mas todo o grupo de envolvidos passe a optar por organizações que se preocupem com o bem estar social. $O$ autor (2006) salienta que:

A gestão socialmente responsável agrega valor aos negócios não porque é mais um modelo e conduta que deve ser seguido, 
mas pela mudança de cultura e pelas atitudes concretas tomadas pelas empresas que a adotam, implicando mudança de mentalidade dos indivíduos e transformando a responsabilidade social em uma forma de atuação global, que envolve todas as relações e ações da organização e das pessoas ligadas a ela.

Para Grabrielle (2008), trabalhar a RSC como mera filantropia ou marketing social é um pensamento errôneo. Para a autora, trata-se de um processo de reflexão e preocupação com os impactos que as atividades empresariais podem gerar para toda a sociedade. A autora menciona que ao fazer da RSC uma parte integrante e fundamental de todas as suas atividades, as empresas conquistarão muito mais do que meramente marketing institucional, também a construção de uma organização sólida, competitiva, com reconhecimento perante todo o grupo de envolvidos, além de contribuir para a preservação dos recursos ambientais e culturais.

O que se observa no geral nas linhas de pensamento existentes é que para atuar de maneira socialmente responsável, as organizações não podem somente procurar promover campanhas promocionais que divulguem suas práticas com o único objetivo de agregar valor aos seus produtos e diferencial competitivo no mercado. Isso porque o consumidor está cada vez mais consciente e essa "máscara" tende a cair cedo ou tarde. É preciso estruturar a cultura organizacional em ações pautadas na ética e na responsabilidade social. De acordo com Azambuja (2001, apud TREVISAN, 2002, p. 7):

[...] por mais louvável que seja uma empresa ao construir uma creche ou um posto de saúde na sua comunidade, a sua generosidade em nada adiantará se, ao mesmo tempo, estiver poluindo o único rio local ou utilizando matéria-prima produzida em fábricas irregulares, que empregam trabalho infantil.

Para Trevisan (2002), a empresa que utilizar da RSC para explorar causas sociais de forma inadequada será identificada pelo mercado como desonesta e hipócrita e terá sua marca prejudicada.

Para Azambuja (2001, apud TREVISAN, 2002, p. 5) "a organização mais ética do espaço econômico decorre da percepção de que padrões de comportamento meramente oportunistas terminam por ser insustentáveis". 
Os discursos explicitados levam ao entendimento que a RSC pode ser utilizada pelas empresas como marketing social, construindo uma imagem sólida, agregando valor ao produto e serviço, gerando diferencial competitivo no mercado, mas, que tudo isso deve ser acompanhado de uma postura ética assumida perante todo o grupo de envolvidos, desde seus consumidores, até seus funcionários, fornecedores e demais.

Apesar de que para alguns autores como Soares (2004, p. 12), "não há - que se falar em nova postura ética perante 0 trabalhador enquanto perdurarem a compra da força de trabalho e a detenção dos meios de produção pelo capital", e ainda salienta por Sweezy (1977, p. 12), "é preciso que todos compreendam que o capitalismo realmente é, e porque sua aparente necessidade e inevitabilidade são, de fato, a pele de cordeiro para ocultar 0 puro interesse próprio de uma escassa minoria."

O discurso da autora nos faz pensar se realmente o compromisso para com todos os envolvidos pode ser aliado às estratégias das organizações e se existe um discurso verdadeiro que regula os interesses econômicos aos sociais.

Para Trevisan (2002), a empresa deve agir profissionalmente dando transparência aos compromissos assumidos, podendo nesse aspecto construir uma imagem verdadeiramente positiva perante a sociedade.

Observamos que a questão é bastante polêmica e há muito a ser discutido. Mas espera-se a conscientização das organizações a respeito do impacto causado na sociedade, seja no social, cultural, ou ainda, pela utilização de recursos naturais e a degradação do meio ambiente, dentre outros aspectos.

\subsubsection{A teoria dos Stakeholders}

Para orientar as estratégias de atuação das empresas quanto a sua responsabilidade social é importante conhecer a teoria dos stakeholders. De acordo com Parente (2006, p. 25), o conceito de stakeholders "tornou-se 
indispensável para o entendimento das relações entre as empresas e as diversas partes envolvidas na sociedade."

Para Fearn-Banks (1996, apud PARENTE, 2006, p. 26), stakeholders são definidos como " indivíduos que estão ligados a uma organização ou que apresentam interesses em uma organização e são afetados pelas decisões tomadas por ela".

Esse grupo de envolvidos é assim definido por Karkloti (2006), como stakeholders, e nele incluem-se todos os quais afetam ou são afetados pelas atividades da empresa, desde seus clientes, funcionários, governo, comunidade, fornecedores, entre outros.

Vários autores como Drucker (1976), mencionam que a gestão social desempenhada pelas empresas é uma forma de devolver ou recompensar a todo o grupo de envolvidos, a utilização dos recursos naturais, sociais e econômicos, assumindo sua parcela de responsabilidade perante a sociedade.

Ao contrário do pensamento de Friedman, citado por Ashley (2004), que o autor enfatiza que a organização existe para preservar o interesse de seus acionistas, maximizando seus lucros, na teoria dos stakeholders a ideia é considerar o interesse de todos os grupos afetados por ela.

Parente (2006), Karkotli (2006) e Ashley (2004), relacionam os principais grupos de interesse, sendo eles:

$\checkmark$ Acionistas: nesse sentido os autores destacam a importância de uma gestão competente nos negócios voltada para a responsabilidade junto aos seus acionistas, que esperam retorno a respeito dos capitais investidos. Nesse sentido, cabe à empresa alcançar o lucro e a satisfação de seus investidores;

$\checkmark$ Funcionários: sob esse aspecto, os autores ressaltam que a forma de tratamento dada aos seus colaboradores pode criar uma imagem da organização podendo ser boa ou má. Eles apontam que o cumprimento da legislação trabalhista é um requisito mínimo a ser respeitado, mas deve estar aliado a outros fatores como manter um bom clima organizacional, segurança no trabalho, igualdade de oportunidades, uma política salarial e de incentivos, além de respeito, atenção e dignidade. 
$\checkmark$ Meio ambiente: os autores apontam para o que se define como desenvolvimento sustentável, com ações que possam integrar a proteção ao meio ambiente e a utilização correta dos recursos naturais.

$\checkmark$ Consumidores e Clientes: esse aspecto é abordado por Parente (2006), que destaca a sua satisfação como elemento fundamental para as organizações, e que pode ser alcançada por meio de uma política justa de preços, propagandas éticas e produtos de qualidade que principalmente não ofereçam riscos à saúde dos clientes.

$\checkmark$ Comunidade: nesse eixo os autores inserem o contexto de ações locais que possam trazer benefícios, qualidade de vida, inserção social, a comunidade local de que fazem parte. Como por exemplo, apoio a organizações do terceiro setor, doações, parcerias, entre outros.

$\checkmark$ Fornecedores: Para Ashley (2004, p. 38), a orientação "faz com que a responsabilidade social percorra a empresa e se transponha para a cadeia de produção e consumo", ou seja, a prática da responsabilidade social atinge até a matéria prima ou produtos utilizados para o comércio, exigindo das empresas a seleção de fornecedores que também utilizem da ética social em seus negócios. Para Parente (2006), ainda existe outra ação possível que seria a valorização de pequenos produtores da região, atendendo às condições de qualidade e preço. A utilização desses como fornecedores podem favorecer a geração de emprego e renda.

$\checkmark$ Governo ou Estado: Ashley (2004, p. 38) ainda acrescenta esse grupo, em que a responsabilidade social das empresas está no simples "cumprimento de suas obrigações definidas e regulamentadas em lei".

De acordo com o conceito de stakeholders, se torna necessário um planejamento por parte da organização para atender à diferentes grupos com necessidades e interesses diferentes.

Para Ashley (2004), se uma empresa estabelece como prioridade somente seu desempenho financeiro, sua responsabilidade social está voltada para com seus acionistas e investidores e esse direcionamento vai refletir a respeito dos demais stakeholders envolvidos. A autora salienta que, ao olhar 
para os diferentes grupos envolvidos existe uma "distribuição de poder entre as diversas relações da empresa, refletida nos processos de criação e de distribuição da riqueza gerada pelo empreendimento" (ASHLEY, 2004, p. 40).

A teoria dos stakeholders, explicitada pelos autores, demonstra que para agir de maneira responsável as organizações devem considerar todos os envolvidos com os quais essa atua direta ou indiretamente, assumindo então como escreve Drucker (1976), nada mais que sua parcela de responsabilidade perante a sociedade.

\subsubsection{Os caminhos da responsabilidade social no Brasil}

Considerando os aspectos abordados até o momento é importante analisar dentro da bibliografia existente, o que os autores relatam a respeito das práticas das empresas brasileiras. De que maneira a responsabilidade social está inserida no contexto brasileiro.

Para Ashley (2004, p. 75), responsabilidade social ainda é um tema em desenvolvimento no Brasil. Para a autora ainda não houve nenhum grande feito que merecesse menção honrosa nas diversas mídias existentes. Apesar de concluir que existe uma crescente mudança do pensamento dos empresários brasileiros e a percepção por parte desses em adequar suas políticas. A autora ainda levanta uma questão interessante: "O que se entende por responsabilidade social no Brasil?".

Segundo a autora, é fundamental que o conceito de responsabilidade social no Brasil se desenvolva a partir de visões coerentes e conscientes quanto à verdadeira função de uma empresa socialmente responsável. Ainda, que não devemos esperar que as empresas adotem estratégias tendo por base ações desenvolvidas em países de primeiro mundo, já que a cultura de cada país influência as decisões a serem tomadas.

Almeida (1999, apud ASHLEY, 2004, p. 79) descreve a atuação esperada para o cenário brasileiro:

Assim a atuação das empresas deve se calcar em valores fundamentais da vida em sociedade no âmbito social, 
econômico e ambiental, como direitos humanos, dos funcionários, colaboradores da empresa e dos grupos de interesse; proteção ambiental; envolvimento comunitário; relação com fornecedores e clientes; monitoramento e avaliação de desempenho.

Parente (2006) discorre a respeito do importante aliado que se torna o setor varejista brasileiro às possibilidades de se atuar de forma socialmente responsável, focando em ações para o beneficio da comunidade. O autor menciona o poder que as organizações têm na luta pela implantação de um modelo de gestão social. Para o autor, o movimento pela responsabilidade corporativa no âmbito brasileiro está crescendo e com ele a percepção de se ganhar vantagem competitiva no mercado com consumidores e clientes cada vez mais conscientes. Mas, ressalta que estudiosos entendem que 0 movimento somente caminhará a passos largos se forem observados 0 interesse de todo o grupo de stakeholders. Para Trevisan (2002, p. 3):

Cada vez mais as empresas estão se defrontando com a necessidade de incorporar a responsabilidade social aos seus objetivos de lucro. A ação socialmente responsável das empresas já ultrapassou o estagio de mera tendência para se transformar gradativamente em estratégia corporativa.

De acordo com IPEA (2006), no período de 2000 a 2004, houve um crescimento significativo na adoção de práticas sociais pelas empresas brasileiras. A pesquisa indica um número aproximado de 600 mil organizações com práticas em ações sociais. $O$ Instituto Ethos informa em sua página na internet que possui um número de 1.426 empresas associadas, que essas possuem faturamento anual correspondente a $35 \%$ do PIB brasileiro, e empregam cerca de 2 milhões de pessoas.

Para Ashley (2004), ainda existe um número de organizações que por motivos estratégicos preferem não divulgar suas práticas sociais, acreditando que isso pode levar a uma imagem negativa da empresa e que se estaria buscando associar suas práticas na simples busca de vantagem competitiva no mercado.

A autora ainda esclarece que para as quais se faz importante transparecer seu lado social isso deve ser feito de maneira correta, buscando 
integrar todas as variáveis possíveis existentes no campo da responsabilidade social, deixando claro qual é o seu entendimento da responsabilidade social.

Ashley (2004) menciona que a adoção por parte das empresas de um código de ética pode ser a partida inicial para o direcionamento de comportamento de seus membros e desenvolvimento de ações pautadas na responsabilidade social.

Nesse contexto para Soares (2004, p.12), os aspectos abordados em tais códigos são meros regulamentadores a respeito das perspectivas teóricas da ética e da moral, raramente colocados em prática, utilizados apenas pela conveniência ou para dar uma imagem positiva à organização. A autora ainda menciona que "a mera implementação da responsabilidade social corporativa não operacionalizara nenhuma transformação na realidade organizacional."

O que se pode observar é que existe muito a crescer na discussão a respeito do tema, mas diversas pesquisas, estudos, apontam para caminhos e orientações que podem ser seguidas pelas empresas brasileiras. Cabe aos empresários brasileiros pensar em um desenvolvimento sustentável de longo prazo, passando a analisar o interesse do seu grupo de stakeholders como um todo, incorporando não somente as exigências legais para com o Estado ou a gestão financeira para com seus acionistas.

\subsubsection{A responsabilidade social nas Instituições Financeiras}

Alguns autores destacam a relevância das ações sociais por parte das organizações de grande porte, considerando o elevado poder econômico que as mesmas possuem na sociedade. Quanto mais elevado o poder econômico, maior serão suas responsabilidades junto à sociedade. Nesse sentido alguns estudos apontam para a responsabilidade social dentro das Instituições Financeiras.

Tendo como objeto de estudo desse trabalho a análise da percepção dos funcionários de instituição financeira quanto às práticas desenvolvidas no âmbito corporativo, é interessante divulgar as pesquisas existentes na área. 
No âmbito das instituições financeiras, criou-se a Febraban - Federação Brasileira de Bancos em 1967, com o objetivo de "fortalecer o sistema financeiro e suas relações com a sociedade e contribuir para 0 desenvolvimento econômico, social e sustentável do país."

A organização publica o Relatório Social do setor bancário em que ela apresenta o envolvimento e a participação dessas organizações em ações voltadas a sociedade. De acordo com a própria Febraban:

Desde 1993 a Febraban vem publicando anualmente, de forma pioneira no meio empresarial, o Relatório Social do setor bancário, no qual essas iniciativas são relatadas de modo detalhado, em diversas áreas: ações internas, voltadas para as equipes dos bancos; ações voltadas para a inclusão bancárias das pessoas; ações voltadas para a inclusão social e investimentos sociais; ações voltadas para a valorização da diversidade brasileira.

Para Oliveira et al. (2009), as instituições financeiras têm papel relevante na contribuição para a questão ambiental no país com a destinação de recursos para investimentos de forma autossustentável, analisando e coordenando a viabilidade desses negócios.

Para o autor a parcela de responsabilidade dos bancos cresce na medida em que são grandes influenciadores do meio econômico e de desenvolvimento, com a obrigação de manter uma conduta pautada em ética em todos os setores, seja no econômico, social e ambiental. Ainda, mencionam as vantagens e benefícios que os bancos obtêm na sua imagem perante a sociedade com o apelo de empresa socialmente responsável, por isso a necessidade da adoção de uma postura ética.

Para Hodgson (2002, apud OLIVEIRA, et al., 2009), os bancos têm que assumir sua responsabilidade quanto ao destino dos recursos disponibilizados aos clientes, conhecendo de que forma farão uso do dinheiro.

Os bancos são captadores de recursos financeiros e viabilizam empréstimos e investimentos fomentando a economia. Nesse sentido é importante, como descreve o autor, a necessidade de conhecer seus clientes, destinando a liberação de recursos a investimentos que possam aliar benefícios à sociedade, inclusive prestando consultoria ao seu cliente, como orientador e ainda como fiscalizador. 
Karkotli (2006) reforça a responsabilidade atribuída ao setor bancário pela sua grande influência econômica junto a sociedade.

Ashley (2004) faz um estudo a respeito da importância da responsabilidade do BACEN - Banco Central do Brasil perante a sociedade. A autora destaca a relevância que as organizações públicas que representam 0 Estado têm quanto ao reposicionamento em suas ações, atuando de forma participativa na sociedade, regulamentando e fiscalizando a destinação de recursos. Ainda, menciona a falta de conhecimento por parte do cidadão nas ações e na responsabilidade desenvolvidas por instituições financeiras e como essas influenciam suas vidas. Para a autora, essa falta de consciência da sociedade aumenta a responsabilidade do BACEN, que deve se esforçar para comunicar e envolver a sociedade.

Para Brandão (2011), tomando por base os conceitos de responsabilidade social definidos por autores como Ashley e o Instituto Ethos, o autor escreve que não existe responsabilidade social junto às instituições financeiras:

O cotidiano dos consumidores bancários é de vivenciar filas exorbitantes, juros abusivos, vendas casadas, colaboradores insatisfeitos, gerentes que praticam atendimentos engessados e apenas focados na cartela de clientes que possuem alta ou média movimentação financeira.

O autor ainda informa que:

Responsabilidade Social Empresarial está relacionada diretamente com a ética e transparência na gestão dos negócios e deve refletir-se nas decisões cotidianas que podem causar impactos na sociedade, no meio ambiente e no futuro dos negócios. De um modo mais simples, podemos dizer que a ética nos negócios ocorre quando as decisões de interesse de determinada empresa também respeitam o direito, os valores e os interesses de todos aqueles que, de uma forma ou de outra, são por elas afetados.

Ainda são poucos os estudos e opiniões relevantes a respeito da atuação das instituições bancárias brasileiras. Os autores partem para uma colocação a respeito da importância e a relevância que a sua atuação tem na sociedade, além do poder de possíveis transformações. 
Observa-se pela opinião dos autores aqui relacionados que é grande a responsabilidade atribuída às instituições financeiras, indo além do meio econômico, partindo também para o social e ambiental.

A sociedade espera que além da divulgação na mídia por meio de propagandas, com apelo em produtos e serviços destinados a uma melhor qualidade de vida, existam atitudes e práticas reais, equalizadas com o alto poder econômico que essas possuem. 


\section{MÉTODOS E TÉCNICAS DE PESQUISA}

De acordo com Gil (1999, apud SILVA e MENEZES, 2001, p. 19), a pesquisa é definida como:

Um processo formal e sistemático de desenvolvimento do método cientifico. O objetivo fundamental da pesquisa é descobrir respostas para problemas mediante o emprego de procedimentos científicos.

O objetivo dessa pesquisa foi analisar a percepção que os funcionários de agências selecionadas do Banco $X$ têm em relação às práticas de gestão em responsabilidade social desenvolvidas pela empresa em seu ambiente interno. Assim, se propõe desenvolver um diagnóstico por meio de suas opiniões quanto às práticas sociais promovidas pela empresa. Evidenciando ainda, a existência da aplicabilidade e viabilidade dos discursos propostos pela empresa dentro do cotidiano dos funcionários.

Como forma de organizar e entender os procedimentos e métodos científicos utilizados nesse trabalho, esse capítulo está dividido nos seguintes tópicos:

$\checkmark$ Tipo e descrição geral da pesquisa (técnicas de pesquisa escolhidas para coletar os dados);

$\checkmark$ Caracterização da Organização;

$\checkmark$ Participantes do estudo;

$\checkmark$ Instrumento(s) de pesquisa;

$\checkmark$ Procedimento de coleta e análise de dados.

\subsection{Tipo e descrição geral da pesquisa}

Segundo Acevedo e Nohara (2009), primeiramente se faz necessário descrever as variáveis que são propostas, ou seja, o que se pretende analisar, investigar ou compreender. 
As variáveis aqui utilizadas foram formuladas com base no conteúdo do referencial teórico (capítulo 2) e estão relacionadas aos objetivos do estudo:

1. Variável - As práticas sociais propostas no âmbito interno da Corporação;

2. Variável - Interação entre o discurso pronunciado e as práticas desenvolvidas;

3. Variável - Viabilidade e aplicabilidade das ações desenvolvidas, analisadas pela opinião do público pesquisado.

$\mathrm{Na}$ primeira variável se pretende identificar por meio da análise documental quais são as ações e estratégias que a empresa se propõe voltadas para a gestão social no que se refere ao atendimento das necessidades de seu público interno. Essa análise documental será realizada com base nas informações que a própria empresa disponibiliza em sua página na internet e intranet.

Na segunda variável, se faz importante para o contexto da pesquisa analisar se existe coerência entre o discurso que a empresa promove com as práticas executadas dentro das dependências. Essa investigação será realizada junto aos participantes do estudo, por meio de questionário elaborado com questões abertas que possam descrever o nível de conhecimento das ações e sua efetividade.

E na terceira variável, para concluir a pesquisa, analisar a opinião do seu público interno quanto a viabilidade das ações, assim como sua efetiva aplicabilidade no cotidiano. Esta variável ainda tem o objetivo de demonstrar o nível de satisfação e buscar conhecimento a respeito dos aspectos positivos e negativos que os funcionários percebem e será realizada por meio de questionário aplicado.

De acordo com os objetivos propostos pelo estudo, a abordagem da pesquisa será descritiva. Conforme Gil (1999, apud SILVA e MENEZES, 2001), a pesquisa descritiva tem por objetivo descrever um fenômeno pesquisado ou estabelecer relações entre suas possíveis variáveis, assumindo uma forma geral de levantamento de dados.

Quanto à natureza das variáveis, essas foram classificadas pelo aspecto qualitativo e será realizada a coleta de dados no ambiente natural da 
organização, tendo o investigador a responsabilidade de analisar e interpretar os dados coletados.

De acordo com Zanella (2006), na pesquisa qualitativa a análise dos dados é feita por meio de interpretação dos dados coletados, não mensurando seus resultados estatisticamente. Cabe ao entrevistador a capacidade de uma percepção apurada e profunda dos dados. A autora ainda salienta que 0 ambiente natural é a fonte direta para a coleta de dados e o pesquisador é o instrumento-chave.

No que diz respeito aos procedimentos técnicos práticos utilizados para efetuar a pesquisa e quanto ao levantamento dos dados, tomam-se por base os conceitos definidos por Gil (1999, apud SILVA E MENEZES, 2001) e propõe-se utilizar os métodos de:

$\checkmark$ Pesquisa bibliográfica: serão realizadas consultas e citações de materiais já publicados na área, como livros, artigos e material disponibilizado na internet e intranet;

$\checkmark$ Pesquisa documental: tendo por base a consulta a material disponibilizado pelo próprio Banco $\mathrm{X}$ em sua página na internet $\mathrm{e}$ também na intranet;

$\checkmark$ Levantamento de dados por meio de questionário: por meio de questionário elaborado com perguntas abertas aplicado junto ao público estudado.

\subsection{Caracterização da organização}

A empresa selecionada para a pesquisa é uma instituição financeira, atuante no setor bancário brasileiro. De acordo com dados que a própria empresa divulga em sua página na internet, a mesma se intitula pioneira no setor bancário e um dos principais agentes do desenvolvimento econômico e social do país. Informa ainda, que suas políticas e diretrizes são pautadas pela ética e responsabilidade socioambiental.

De acordo com as informações publicadas, a empresa segue uma linha estratégica voltada para o desenvolvimento sustentável, pautando todos os 
seus processos, produtos e serviços pela análise dos impactos sociais e ambientais.

No discurso a respeito de Processos e Gestão, a empresa relaciona as ações e práticas desenvolvidas junto ao seu grupo de stakeholders, envolvendo funcionários, fornecedores, clientes, acionistas, credores, parceiros, concorrentes, comunidades, governo e meio ambiente.

No que diz respeito aos funcionários, clientes internos da organização, a empresa informa ações como: acessibilidade, qualidade de vida no trabalho, pró-equidade de gênero, educação, a inclusão de dependentes do mesmo sexo em planos de saúde e previdência e programa de ascensão profissional.

A empresa registra em seu site a adoção de normas orientadoras como missão, valores, código de ética, carta de conduta, entre outros.

\subsection{Participantes do estudo}

Segundo Barbetta (2005, apud ZANELLA, 2006, p. 93):

[...] população é o conjunto de elementos que formam o universo de nosso estudo e que queremos abranger no nosso estudo. São os elementos para os quais desejamos que as conclusões oriundas da pesquisa sejam válidas.

Para Zanella (2006, p. 93), "a escolha de determinada população depende dos objetivos da pesquisa, das características a serem levantadas e dos recursos disponíveis". Para subsidiar essa pesquisa, foram selecionadas quatro agências do Banco $X$ do Estado de Rondônia, em que foram observadas as seguintes características:

$\checkmark$ Agências de atendimento a varejo do mesmo porte e mesmo segmento localizadas na região norte do estado de Rondônia;

$\checkmark$ Acessibilidade: todas se localizam em cidades situadas na margem da BR-364, com atendimento a cidades que se assemelham em suas características econômicas;

$\checkmark$ Possuem número de funcionários equivalentes; 
$\checkmark$ As agências selecionadas foram: Ariquemes, Cacoal, Vilhena e JiParaná.

Quanto às características atribuídas aos participantes do estudo, foram selecionados os que apresentam semelhanças em suas atribuições dentro da empresa, sendo:

$\checkmark$ Funcionários concursados, lotados nas agências selecionadas, ocupando cargos aos quais não se atribuem responsabilidades gerenciais, sendo denominados como postos efetivos, enquadrados dentro da mesma faixa salarial, com desempenho de funções semelhantes.

O motivo pelo qual se optou selecionar para a pesquisa participantes que não ocupassem cargos comissionados foi para preservar e obter um resultado o mais próximo da realidade possível. Visto que os cargos comissionados são tidos como cargos de confiança, os quais delegam serviços aos postos efetivos, estando inseridos em outro segmento corporativo da empresa.

No que se refere à quantidade de participantes envolvidos no estudo, foram selecionados todos os funcionários com as características acima, das quatro Agências selecionadas, totalizando um número de 50 (cinquenta) sujeitos.

Não foi realizada distinção ou separação quanto aos participantes do estudo por sexo, idade, escolaridade ou tempo de serviço, pois todos os selecionados encontram-se inseridos no contexto da pesquisa.

\subsection{Instrumentos de pesquisa}

De acordo com Zanella (2006), dentre as técnicas de coletas de dados quando da utilização de pesquisa qualitativa, o pesquisador pode utilizar da aplicação de questionário e análise documental.

A pesquisa desenvolvida nesse trabalho foi aplicada com base em dois instrumentos de pesquisa, por meio de questionário elaborado com perguntas 
com respostas abertas e análise documental com base nas informações que a própria empresa registra em sua página na internet e em seu ambiente de intranet.

Seguindo os conceitos de Zanella (2006), o questionário pode ser estruturado com perguntas para diagnosticar a opinião e avaliação do problema da pesquisa.

Considerando os parâmetros e conceitos desenhados pela autora, o questionário (apêndice A) foi elaborado tendo em sua página inicial, uma pequena introdução, onde constam informações a respeito do contexto da pesquisa, descrevendo sua importância e relevância, bem como garantindo que as respostas serão tratadas de forma confidencial, preservando a identidade dos participantes.

\subsection{Procedimentos de coleta e de análise de dados}

Os procedimentos adotados para análise da primeira variável proposta, que têm por objetivo identificar e descrever quais as ações e estratégias que a empresa se propõe a promover em seu ambiente interno, se realizou por meio de análise documental, com acesso ao site da própria empresa em sua página na internet.

A análise do resultado dos questionários aplicados se deu por meio da análise de conteúdo, utilizando do conceito atribuído por Bardin (1977, apud CAMARÂ, 2006, p. 3), o qual a conceitua como:

\footnotetext{
"um conjunto de técnicas de análise das comunicações visando a obter, por procedimentos sistemáticos e objetivos de descrição do conteúdo das mensagens, indicadores (quantitativos ou não) que permitam a inferência de conhecimentos relativos às condições de produção/recepção (variáveis inferidas) destas mensagens".
}

Segundo o autor, o procedimento de análise dos dados se inicia por uma leitura geral dos dados coletados, procurando a partir daí evidenciar as categorias de análise, exploração do material e por fim análise e interpretação dos dados. 
A análise seguiu os passos sugeridos por Godoy (1995, apud CAMARÂ, 2006), que seguindo os conceitos de Bardin, coloca a análise de conteúdo em três fases fundamentais: pré-análise, exploração do material e tratamento dos resultados (a inferência e a interpretação).

$\mathrm{Na}$ pré-análise foi realizada a organização do material e leitura dos dados coletados, evidenciando as categorias de análise, temas, palavraschave. Logo após se deu início a exploração do material e construção das categorias para análise, compreendendo temas, recortes das respostas dos participantes do estudo. De acordo com Bardin (1977, apud CÂMARA, 2006, p. 5):

[...] as categorias devem possuir certas qualidades como: exclusão mútua - cada elemento só pode existir em uma categoria; homogeneidade - para definir uma categoria, é preciso haver só uma dimensão na análise. Se existem diferentes níveis de análise, eles devem ser separados em diferentes categorias; pertinência - as categorias devem dizer respeito às intenções do investigador, aos objetivos da pesquisa às questões norteadoras, às características da mensagem, etc.; objetividade e fidelidade - se as categorias forem bem definidas, se os índices e indicadores que determinam à entrada de um elemento numa categoria forem bem claros, não haverá distorções devido à subjetividade dos analistas; produtividade - as categorias serão produtivas se os resultados forem férteis em inferências, em hipóteses novas, em dados exatos.

Após a exploração do material e construção das categorias realizou-se a interpretação dos dados, relacionando os resultados com a base teórica e as variáveis do estudo.

Importante destacar que a construção das categorias foi elaborada de acordo com o propósito e objetivos das variáveis do estudo e ainda, com base nas opiniões apresentadas pelos participantes do estudo.

Quanto ao questionário aplicado, a pesquisa foi realizada nas quatro agências selecionadas no decorrer do mês de Julho/2011. Foram distribuídos 50 (cinquenta) questionários, entregues aos participantes do estudo via malote, devidamente endereçados a um funcionário escolhido pelo investigador, o qual foi contatado anteriormente por telefone, para combinar a entrega dos questionários aos envolvidos na pesquisa. Foi utilizado um único envelope 
lacrado para cada uma das agências. Dos 50 questionários entregues, foram respondidos e devolvidos, também via malote, o total de 17 (dezessete), apenas de três agências envolvidas no estudo sendo Ji-Paraná, Cacoal e Vilhena. Em novo contato com o funcionário que aceitou promover a entrega dos questionários, na agência de Ariquemes, foi informada a dificuldade junto aos demais colegas que alegaram que não haveria tempo para respondê-lo, sendo que no período da pesquisa foram feitas várias tentativas de recolhimento dos mesmos sem sucesso.

Aqui ressalta-se as limitações para aplicação da pesquisa, quanto ao envolvimento de todos os participantes selecionados, onde eles demonstram resistência para a participação justificando quanto a falta de tempo para responder o questionário, sendo que foram necessários vários contatos para conseguir recolher o máximo de questionários possíveis.

Para melhor qualificação da pesquisa o quadro 1 descreve o perfil dos participantes do estudo:

\begin{tabular}{|c|c|c|c|c|}
\hline $\begin{array}{c}\text { Identificação } \\
\text { fictícia do } \\
\text { funcionário }\end{array}$ & Idade & Sexo & Escolaridade & $\begin{array}{c}\text { Tempo de serviço na } \\
\text { empresa em anos }\end{array}$ \\
\hline Q-1 & 21 & $\mathrm{~F}$ & Superior incompleto & 2 \\
\hline Q-2 & 29 & $\mathrm{M}$ & Superior incompleto & 6 \\
\hline Q-3 & 25 & $\mathrm{~F}$ & Superior incompleto & 7 \\
\hline Q-4 & 28 & $F$ & Superior & 6 \\
\hline Q-5 & 37 & $F$ & Superior incompleto & 11 \\
\hline Q-6 & 38 & $\mathrm{~F}$ & Superior em andamento & 7 \\
\hline Q-7 & 31 & $\mathrm{~F}$ & Pós-graduação & 5 \\
\hline Q-8 & 40 & $\mathrm{~F}$ & Superior incompleto & 3 \\
\hline Q-9 & 32 & $\mathrm{~F}$ & Mestrado & 8 \\
\hline Q-10 & 25 & $\mathrm{~F}$ & Superior incompleto & 3 \\
\hline Q-11 & 46 & $\bar{M}$ & Superior & 32 \\
\hline Q-12 & 34 & $\mathrm{~F}$ & Superior incompleto & 7 \\
\hline Q-13 & 36 & $\mathrm{M}$ & Superior incompleto & 11 \\
\hline Q-14 & 24 & $M$ & Ensino médio & 3 \\
\hline Q-15 & 30 & $M$ & Superior & 9 \\
\hline
\end{tabular}




\begin{tabular}{|l|l|l|l|l|}
\hline Q-16 & 35 & M & Superior & 9 \\
\hline Q-17 & 28 & F & Superior & 3 \\
\hline
\end{tabular}

Quadro 1 - Título: Qualificação dos participantes da pesquisa Fonte: Elaborado pela autora. 


\section{RESULTADOS E DISCUSSÕES}

No presente capítulo são apresentados os resultados encontrados, bem como sua análise e interpretação dos dados e posterior discussão, relacionando os resultados com a bibliografia apresentada e as variáveis do estudo.

\subsection{Práticas propostas no âmbito interno da corporação.}

A instituição financeira aqui denominada Banco $X$, apresenta em sua página na internet, as propostas desenvolvidas junto ao seu grupo de stakeholders internos.

O propósito de relacionar os dados divulgados pela empresa é ter 0 conhecimento das ações que desenvolve, com 0 intuito de relacionar posteriormente com a opinião dos participantes envolvidos no estudo. Dessa forma segue a análise documental dos dados pertinentes.

A empresa relaciona as seguintes propostas:

$\checkmark$ Acessibilidade: nesse conceito a empresa menciona a busca por conciliar os interesses do conglomerado com os interesses dos funcionários e suas entidades representativas, como sindicatos;

$\checkmark$ Pró-Equidade de Gênero: está relacionado à promoção de discussões que desenvolvam políticas e ações que estimulem práticas de gestão, para promover a equidade de gênero;

$\checkmark$ Qualidade de Vida no Trabalho - QVT: nesse aspecto a empresa visa promover ações para a melhoria da qualidade de vida dos funcionários, elencando linhas de ações que vão de comunicação, educação, experimentação e suporte;

$\checkmark$ Educação - A empresa menciona a Universidade Corporativa do Banco do Brasil, que segundo a mesma, têm por objetivo auxiliar os funcionários a aprimorar seus talentos, crescer profissionalmente e contribuir para a realização de negócios. Ainda, salienta que se trata de 
um recurso estratégico que o Banco utiliza para se posicionar na indústria financeira e fortalecer sua imagem institucional. Os cursos e treinamentos são oferecidos nas formas de: ambiente virtual de aprendizagem, presenciais e auto instrucionais com materiais (apostilas) disponíveis;

$\checkmark$ Inclusão de Dependente Companheiro(a) do Mesmo Sexo na Cassi/Previ (plano de saúde e previdência privada): A empresa menciona que a inclusão de companheiros(as) de mesmo sexo nos planos assistências de saúde e previdência privada são compromissos estabelecidos nas políticas de responsabilidade socioambiental;

$\checkmark$ Programa Ascensão Profissional: Segundo a empresa, o objetivo é fornecer subsídios para a gestão de carreira do funcionário, envolvendo ações de recrutamento, seleção, comissionamento e orientação profissional. São realizadas provas semestrais de várias disciplinas como marketing, gestão de pessoas, comércio exterior, agronegócios, entre outros. As mesmas são aplicadas por instituição de ensino contratada pela empresa. Trata-se de uma espécie de vestibular, seguindo regras na execução das provas.

Se considerarmos os conceitos atribuídos à responsabilidade social por autores como Karkotli (2006) e Ashley (2004) e suas considerações quanto ao posicionamento das organizações do seu grupo de envolvidos sejam clientes externos ou internos, e comparar às informações que a empresa disponibiliza em sua página, pode-se dizer que o discurso que a mesma promove está alinhado às estratégias de responsabilidade social.

\subsection{Interação entre o discurso pronunciado pela empresa e as práticas desenvolvidas.}

Do conteúdo dos questionários foram extraídas cinco categorias que se encontram sistematizadas no Quadro resumo e ilustradas com verbalizações dos participantes do estudo. 


\begin{tabular}{|c|}
\hline Categorias \\
\hline $\begin{array}{l}\text { 1. "Compromisso com a sociedade, desempenhar ações... que levem aos } \\
\text { funcionários em geral a um melhor ambiente de trabalho, visando a qualidade } \\
\text { de vida num todo." }\end{array}$ \\
\hline $\begin{array}{l}\text { 2. “... integrar funcionários e empresa, através de boas práticas de gestão. } \\
\text { Campanhas... empresa sustentável e ecologicamente correta... programas de } \\
\text { apoio como ECOA, Previ, Cassi, auxilio creche." }\end{array}$ \\
\hline $\begin{array}{l}\text { 3. "... acho interessante e proveitoso para o conhecimento de diversas áreas, } \\
\text { porem não há muito condição de estudo, sendo que o aluno tem que se virar." }\end{array}$ \\
\hline $\begin{array}{l}\text { 4. "Sim, o alongamento é muito benéfico para nossa atividade... dá incentivo, } \\
\text { financiamento, acompanhamento e muita cobrança!!!." }\end{array}$ \\
\hline $\begin{array}{l}\text { 5. "Falta tempo... a essência dos programas são boas, mas não são } \\
\text { efetivos. Infelizmente o banco disponibiliza as ações, mas não o tempo, } \\
\text { mais importante...sei também que depende de cada um." }\end{array}$ \\
\hline
\end{tabular}

Quadro 1: categorias de análise

Fonte: Dados da pesquisa.

Os quadros de 2 a 6, apresentam os resultados seguidos da discussão, de modo sintético, esquematizados nas categorias apresentadas.

\section{CATEGORIA 1}

1. "Compromisso com a sociedade, desempenhar ações... que levem aos funcionários em geral a um melhor ambiente de trabalho, visando à qualidade de vida num todo."

Definição: Os conceitos atribuídos a RSC, pela opinião dos participantes do estudo. Ressalta-se a avaliação como o comprometimento que a empresa deve apresentar para com seus funcionários e sociedade aliando uma melhor qualidade de vida, além de ações que visem o desenvolvimento econômico e social e preservação do meio ambiente.

\begin{tabular}{|c|c|}
\hline TEMA & Exemplos de Verbalizações \\
\hline $\begin{array}{l}\text { RSC X } \\
\text { Qualidade de } \\
\text { vida e qualidade } \\
\text { no ambiente de } \\
\text { trabalho }\end{array}$ & $\begin{array}{l}\text { Q-1 “É um forma estratégica que as empresas encontram de fazer uma } \\
\text { melhor inclusão dos funcionários... consegue-se estimular os mesmos a ter } \\
\text { uma ascensão de carreira... sua preocupação com a qualidade de vida.” } \\
\text { Q-2 “... comprometimento da empresa com seus funcionários e clientes..." } \\
\text { Q-3 “... práticas... visa melhorias no bem estar de seus colaboradores e } \\
\text { comunidade local”. } \\
\text { Q-7 “... é a inclusão de todos os funcionários nas atividades que a empresa } \\
\text { desenvolve.” } \\
\text { Q-8 “... contribuir para o desenvolvimento econômico, juntamente com a } \\
\text { qualidade de vida dos funcionários... bem como da sociedade como um } \\
\text { todo.” } \\
\text { Q-9 "comprometimento de melhorar a qualidade de vida e rede de } \\
\text { relacionamento, além da satisfação no trabalho". } \\
\text { Q-10 “... desempenhar ações... que levem aos funcionários em geral a um } \\
\text { melhor ambiente de trabalho, visando a qualidade de vida num todo." } \\
\text { Q-14 "... combinação de moral e ética, onde se foca no bem estar do } \\
\text { funcionário.... no que tange ao desenvolvimento das atividades, pedindo } \\
\text { posição politicamente correta." } \\
\text { Q-15 "Conjunto de práticas que visam melhorar a qualidade do ambiente de } \\
\text { trabalho desenvolvendo uma melhor relação dos funcionários com o } \\
\text { ambiente de trabalho e a sociedade”. }\end{array}$ \\
\hline $\begin{array}{l}\text { RSC X Ações } \\
\text { voltadas para o } \\
\text { meio ambiente, } \\
\text { desenvolvimento }\end{array}$ & $\begin{array}{l}\text { Q-1 “... acões de caráter social, ambiental e econômico... quanto obter uma } \\
\text { visão de clientes em adquirirem produtos, seguros, voltados à uma } \\
\text { preservação e preocupação com o meio ambiente”. } \\
\text { Q-2 “... comprometimento... vida do planeta de um modo geral". }\end{array}$ \\
\hline
\end{tabular}




\section{CATEGORIA 1}

1. "Compromisso com a sociedade, desempenhar ações... que levem aos funcionários em geral a um melhor ambiente de trabalho, visando à qualidade de vida num todo."

Definição: Os conceitos atribuídos a RSC, pela opinião dos participantes do estudo. Ressalta-se a avaliação como o comprometimento que a empresa deve apresentar para com seus funcionários e sociedade aliando uma melhor qualidade de vida, além de ações que visem o desenvolvimento econômico e social e preservação do meio ambiente.

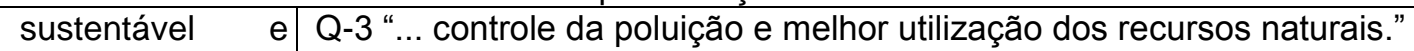

responsabilidade Q-4 "... compromisso com o meio ambiente e geração de riquezas sem para com a prejudicar."

sociedade $\quad$ Q-6 “... comprometimento com o meio ambiente... social... proporcionar desenvolvimento sustentável, visando melhoria social com ética."

Q-10 "... compromisso com a sociedade... visando a qualidade de vida num todo."

Q-11 "Não visar só lucro, devolver a sociedade parte desse lucro visando melhorar a vida das pessoas e se comprometer com a sustentabilidade."

Q-13 “... para garantir sua sobrevivência devem ter seus olhos voltados para a área social."

Q-16 "... entendo que as empresas apesar de ter como finalidade o lucro deve também ser responsável pela sociedade... ela acaba interferindo negativamente ou positivamente na sociedade, deve criar meios para

Quadro 2: Categoria 1de análise amenizar os impactos negativos."

Fonte: Dados da pesquisa.

Nessa categoria, grande parte dos envolvidos no estudo faz referência ao comprometimento e responsabilidade das empresas em aliar suas estratégias às ações que proporcionem qualidade de vida aos funcionários, bem como um ambiente favorável às condições de trabalho, proporcionando condições de ascensão e crescimento profissional. Além do aspecto relacionado à qualidade de vida da sociedade e ações pautadas pela ética e moral, juntamente com a preservação e conservação dos recursos naturais do planeta, posição apoiada por autores como Karkotli (2006), Parente (2006) e Ashley (2004).

Ainda pautando-se na posição desses autores se relaciona as verbalizações quanto ao meio ambiente e desenvolvimento sustentável, resultando no conceito de grupo de stakeholders denominado como meio ambiente. Os discursos ainda destacam a importância de ações voltadas para o social, ambiental e econômico, ainda, a parcela de responsabilidade das empresas quanto aos impactos causados na sociedade, além da preocupação da devolução de parte dos lucros auferidos como forma de compensação aos danos causados.

Sob essa perspectiva, ressalta-se a colocação de Ashley (2004), que discorre a respeito dos vários conceitos e significados que a RSC representa. 
Para a autora, a RSC se inicia desde um comportamento ético aliado ao compromisso das empresas para a sociedade como um todo, indo a uma resposta ao impacto causado na sociedade na forma de uma obrigação legal.

As verbalizações que fazem referência ao lucro que as empresas auferem por meio da sociedade, remetem ao pensamento de Drucker (1989), no qual o autor destaca que a empresa que não trabalhar com ênfase em obter ganhos econômicos é irresponsável, mas, salienta a necessidade desta em assumir os impactos causados com tudo e todos com que se relaciona.

Quando as verbalizações correspondem a ações voltadas aos funcionários os autores salientam que os colaboradores podem criar uma imagem negativa ou positiva da organização e estão atentos a fatores como manter um bom clima organizacional, segurança no trabalho, igualdade de oportunidades, uma política salarial e de incentivos, além de respeito, atenção e dignidade.

Os vários discursos relacionados ao conceito de RSC, pela opinião dos participantes do estudo, vão ao encontro da proposta inicial desse estudo, dando subsídios para as análises das demais categorias.

Aqui, procurou-se não estabelecer ou definir um conceito único ou uma concepção correta ou errada a respeito de RSC, mas, evidenciar como os trabalhadores percebem a RSC, como um todo. Tendo como objetivo principal identificar se os mesmos possuem qualquer conhecimento a respeito do assunto.

2. “... integrar funcionários e empresa, através de boas práticas de gestão. Campanhas... empresa sustentável e ecologicamente correta... programas de apoio como ECOA, Previ, Cassi, auxilio creche."

Definição: Dentre as propostas da empresa na atuação de processos e gestão voltados para o seu grupo de clientes internos, foram lembradas as ações voltadas para a qualidade de vida, controle de consumo de materiais no local de trabalho e são abordados os cursos disponíveis para o aprimoramento profissional".

\begin{tabular}{|c|l|}
\hline \multicolumn{1}{|c|}{ TEMA } & \multicolumn{1}{c|}{ Exemplos de Verbalizaçães } \\
\hline & $\begin{array}{l}\text { Q-1 “... conscientização dos funcionários, em relação a gastos excessivos de } \\
\text { água, papel toalha... uso de materiais recicláveis... qualidade de vida o } \\
\text { exercício laboral”. }\end{array}$ \\
$\begin{array}{l}\text { Práticas de RSC } \\
\text { X Qualidade de } \\
\text { vida e ambiente } \\
\text { de trabalho }\end{array}$ & $\begin{array}{l}\text { Campanhas.... empresa sustegrantável e ecologicamente correta... valorizar o } \\
\text { funcionário, programas de apoio como ECOA, Previ, Cassi, auxilio creche.” } \\
\text { Q-3 “conscientização ambiental: economia de água e energia e a utilização } \\
\text { de papel reciclado. Exercícios físicos com o acompanhamento de } \\
\text { profissionais.” } \\
\text { Q-4 “.... desperdício das riquezas ambientais com o material de consumo do }\end{array}$ \\
\hline
\end{tabular}




\section{CATEGORIA 2}

2. “... integrar funcionários e empresa, através de boas práticas de gestão. Campanhas... empresa sustentável e ecologicamente correta... programas de apoio como ECOA, Previ, Cassi, auxilio creche."

Definição: Dentre as propostas da empresa na atuação de processos e gestão voltados para o seu grupo de clientes internos, foram lembradas as ações voltadas para a qualidade de vida, controle de consumo de materiais no local de trabalho e são abordados os cursos disponíveis para o aprimoramento profissional".

\begin{tabular}{|c|c|}
\hline & $\begin{array}{l}\text { dia a dia... programa QVT. } \\
\text { Q-5 "QVT, pró-equidade de gênero, ECOA, programa de aprimoramento.” } \\
\text { Q-6 “... convênios médicos, odontológicos, benefícios... para a qualidade de } \\
\text { vida dos funcionários.” } \\
\text { Q-7 “... ECOA é um bom exemplo de RS voltada as funcionários.” } \\
\text { Q-8 "ginástica laboral e massagem duas x por semana”. } \\
\text { Q-9 “... minutos de alongamento e massagem.” } \\
\text { Q-12 “Nenhuma”. } \\
\text { Q-13 "Não vejo a empresa muito preocupada com isso”; } \\
\text { Q-15 “... uso racional de copos descartáveis no consumo de água”. } \\
\text { Q-17 “... reaproveitamento de impressões... massagem relaxante...”. }\end{array}$ \\
\hline $\begin{array}{l}\text { Ações voltadas } \\
\text { para o } \\
\text { desenvolvimento } \\
\text { e crescimento } \\
\text { profissional }\end{array}$ & $\begin{array}{l}\text { Q-5 “.... programa de aprimoramento...” } \\
\text { Q-6 “... incentivos a formação profissional, onde a empresa custeia parte dos } \\
\text { ônus, cursos a disposição...” } \\
\text { Q-7 “... o banco tem se preocupado em desenvolver profissionalmente o } \\
\text { funcionário.... não está } 100 \% \text {, mas vem melhorando”. } \\
\text { Q-8 “.... cursos presenciais e a distância, provas de certificação interna.” } \\
\text { Q-10 “.... universidade-bolsas, certificações, cursos e formações”. } \\
\text { Q-11 “.... bolsa de graduação, aprimoramento profissional”. } \\
\text { Q-12 “...não existem essas ações na prática, na teoria é muito bem colocada, } \\
\text { mas na verdade é motivo de riso quando voltada a ação”. } \\
\text { Q-16 “...concretamente nenhuma...cursos auto-instrucionais que na maioria } \\
\text { das vezes não se consegue fazer como as instruções do banco orientam”. } \\
\text { Q-17 “... ajuda de custo de até } 60 \% \text { no curso de graduação. Oferece cursos } \\
\text { de MBA e curso de línguas”. }\end{array}$ \\
\hline
\end{tabular}

Quadro 3: Categoria 2 de análise

Fonte: Dados da pesquisa.

Os exemplos de verbalizações apresentados na Categoria 2 demonstram que a maioria dos participantes do estudo, relaciona ações de economia de materiais de uso diário, como consumo de copos descartáveis, economia de energia e utilização de papel reciclado, como ações que são identificadas no ambiente de trabalho voltadas para os funcionários. Na realidade, são ações que apesar de gerar benefício a toda à sociedade, pela preocupação em conservar o meio ambiente e racionalizar o uso de riquezas naturais, de acordo com os conceitos atribuídos a RSC, norteiam os conceitos do grupo de stakeholders de meio ambiente. No qual Parente (2006), Karkotli (2006) e Ashley (2004), salientam que o desenvolvimento sustentável advém de ações que possam integrar a proteção ao meio ambiente e a utilização correta dos recursos naturais. 
As demais ações identificadas, de acordo com a opinião dos participantes do estudo, são voltadas para a qualidade de vida, como o programa QVT - Qualidade de Vida no Trabalho, mencionando massagens corporais, exercícios físicos, planos assistências para saúde e previdência privada e ainda fazem menção a ECOA - Equipe de Comunicação e Autodesenvolvimento, como uma ferramenta de melhoria no ambiente de trabalho afetando a qualidade de vida dos mesmos. A ECOA trata-se de uma equipe formada pelos funcionários que desenvolve ações como conciliações e discute problemas de relacionamento, promove eventos de confraternização e campanhas diversas.

Três dos respondentes disseram não identificar nenhuma ação voltada para si mesmo, dentro do ambiente de trabalho, tanto em qualidade de vida, nem mesmo em desenvolvimento e aprimoramento profissional. Ainda, mencionam críticas quanto à efetividade das ações, que segundo os mesmos, não são tangíveis na prática.

Quanto ao desenvolvimento e aprimoramento profissional, em resposta aos questionamentos em um primeiro momento, os quais abordam as ações que os mesmos identificam nesse aspecto, apenas 7 dos 17 questionários respondidos apontam para ações nesse sentido. São citadas ações como bolsas e ajuda de custos em graduação, cursos à disposição e as certificações internas. Essas ações de desenvolvimento profissional são previstas pelo Instituto Ethos como ações de RSC.

Dentre os aspectos abordados pelos funcionários, as ações lembradas se relacionam com os indicadores em termos de qualidade vida tendo como práticas exercícios (ginástica laboral e massagens) e no compromisso com o desenvolvimento profissional, por meio dos cursos e treinamentos que os funcionários identificam.

Percebe-se ainda, que aspectos relacionados à remuneração e o cumprimento da legislação trabalhista, bem como planos assistências de saúde e previdência aparecem em minoria nas opiniões relacionadas, ficando evidente que esses aspectos são essenciais para um bom ambiente de trabalho, indo de encontro com as colocações de autores como Parente (2006), Ashely (2004) e Karkotli (2006) que apontam esses como requisitos mínimos 
da RSC voltada ao grupo interno de clientes da empresa, tendo essa como obrigação aliar outros fatores.

\section{CATEGORIA 3}

3. “... acho interessante e proveitoso para o conhecimento de diversas áreas, porem não há muito condição de estudo, sendo que o aluno tem que se virar".

Definição: Na opinião dos pesquisados o programa de certificação interna da empresa para a ascensão profissional pode ser uma ferramenta a ser utilizada pelo quadro funcional, mas depende de melhorias quanto a qualidade e quantidade do conteúdo, além do tempo disponível para o estudo".

\begin{tabular}{|c|c|}
\hline TEMA & Exemplos de Verbalizacões \\
\hline $\begin{array}{l}\text { Programa de } \\
\text { Certificação } \\
\text { Interna X } \\
\text { ascensão } \\
\text { profissional }\end{array}$ & $\begin{array}{l}\text { Q-2 “... forma de seleção natural daqueles que pretendem permanecer e } \\
\text { fazer carreira”. } \\
\text { Q-3 “ Não conheço”. } \\
\text { Q-4 “... é bom... mas, precisa de material compatível com os assuntos } \\
\text { abordados nas provas, principalmente matérias mais específicas”. } \\
\text { Q-5 “... programa interessante, em que o funcionário precisa se envolver com } \\
\text { seu desenvolvimento profissional”. } \\
\text { Q-6 “... acho importante se levada a serio pelo funcionário é uma ótima } \\
\text { ferramenta em busca do conhecimento e aprimoramento... chance p/ crescer } \\
\text { na empresa”. } \\
\text { Q-7 “... acho uma boa iniciativa, porém o banco não fornece o material } \\
\text { adequado para o estudo”. } \\
\text { Q-8 "certificação interna para ascensão profissional, acredito ser válido e } \\
\text { necessário, pois para seguir carreira na empresa é preciso ter qualificação". } \\
\text { Q-9 "Eu acho muito grande a quantidade de materiais para estudar em uma } \\
\text { única prova e deveria ter mais apoio interno para estudas algumas matérias". } \\
\text { Q-10 “... acho interessante e proveitoso para o conhecimento de diversas } \\
\text { áreas, porem não há muito condição de estudo, sendo que o aluno tem que } \\
\text { se virar”. } \\
\text { Q-11 “... é um meio positivo p/ o funcionário crescer dentro da empresa de } \\
\text { acordo com seu esforço e dedicação”. } \\
\text { Q-13 “... acredito que é uma maneira do Banco ver quem esta a fim de } \\
\text { crescer na empresa e que não esta nem ai. Toma o tempo livre do } \\
\text { funcionário, fazendo ele estudar nas suas horas de folga. Acho que poderiam } \\
\text { pensar em algo mais humano”. } \\
\text { Q-14 "Essas praticas são importantes para estabelecermos uma separação } \\
\text { do que queremos alcançar”. } \\
\text { Q-15 “... considero importante para a motivação e valorização dos } \\
\text { funcionários”. } \\
\text { Q-16 “... na minha opinião é injusta. Pois não leva em conta as certificações } \\
\text { reconhecidas pelo MEC - curso superior e pós. Tendo o funcionário que } \\
\text { fazer uma prova para ser habilitado/certificado. } \\
\text { Q-17 “... não conheço muito bem, sei que o funcionário é beneficiado } \\
\text { financeiramente se possuir } 3 \text { certificações relacionadas na área que atua”. }\end{array}$ \\
\hline
\end{tabular}

Quadro 4: Categoria 3 de análise

Fonte: Dados da pesquisa.

$\mathrm{Na}$ categoria apresentada, procurou-se saber a opinião dos participantes quanto ao programa de certificação interna utilizado pela empresa para o comissionamento e recrutamento de pessoas, que de acordo com o que a empresa discursa viabiliza o crescimento, ascensão e desenvolvimento profissional. 
Quando questionados quanto ao conhecimento do programa, a maioria fez comentários a respeito, o que demonstrou certo nível de conhecimento. $\mathrm{Na}$ análise das opiniões, alguns mencionaram ser uma forma normal de seleção e recrutamento, outros colocaram como uma oportunidade de crescimento e ascensão na empresa valorizando o profissional. Mas, evidenciaram críticas quanto à quantidade do material para estudo e a sua qualidade, ainda, o tempo destinado para o estudo, que pelos diálogos se percebe que os estudos ocorrem fora do período de trabalho do funcionário. Apenas dois dos respondentes disseram ter nenhum ou pouco conhecimento do programa.

Intrinsecamente os discursos relacionados reforçam as opiniões de autores como Parente (2006), que menciona as grandes transformações que as empresas sofreram e sofrem, tendo que se adequar as novas necessidades de abranger além de seus problemas econômicos os problemas sociais. Essa nova estratégia corporativa também se faz necessária para se manter competitiva no mercado, mantendo seus profissionais competitivos, qualificados e em constante desenvolvimento.

É importante lembrar Maximiano (2006) que reforça o princípio da RSC, onde a organização existe por meio da sociedade, fazendo uso de todos os seus recursos naturais, sociais e ambientais, ainda, afetando sua qualidade de vida.

Diante das ações que a empresa se propõe, relacionadas na discussão da primeira variável do estudo, ressalta-se que as ações identificadas pelos funcionários (categorias 2 e 3), em um momento se confundem com as práticas voltadas para o meio ambiente e em outro são percebidas ações que voltam-se para a qualidade de vida, essa com bastante ênfase, aparecendo em vários discursos.

O que se pode perceber dentro das verbalizações categorizadas é que existe uma consciência quanto ao conceito de RSC e visualização de algumas das práticas que a empresa se propõe ao funcionalismo, essas mais ligadas à qualidade de vida e algumas relacionadas ao desenvolvimento profissional. 


\section{CATEGORIA 4}

4. "Sim, o alongamento é muito benéfico para nossa atividade... dá incentivo, financiamento, acompanhamento e muita cobrança".

Definição: Pela opinião dos participantes do estudo, evidencia-se os benefícios em relação as atividades laborais, nos aspectos negativos se destaca a ênfase no tempo para a realização das ações que a empresa propõe. No envolvimento e participação das ações novamente se menciona o tempo como principal entreposto.

\begin{tabular}{|c|c|}
\hline TEMA & Exemplos de Verbalizações \\
\hline $\begin{array}{l}\text { Aspectos } \\
\text { Positivos }\end{array}$ & $\begin{array}{l}\text { Q-1 “...melhor rentabilidade para a empresa e conscientização no meio } \\
\text { ambiente.” } \\
\text { Q-2 “... a busca pela superação, entre elas a qualidade de vida do } \\
\text { funcionário... a capacitação possibilita adquirir habilidades profissionais e } \\
\text { melhor desempenho profissional.” } \\
\text { Q-3 “... sim, na qualidade de vida.” } \\
\text { Q-4 "Sim, o alongamento é muito benéfico para nossa atividade... dá } \\
\text { incentivo, financiamento, acompanhamento e muita cobrança!!!.” } \\
\text { Q-5 “...melhora a interação entre os funcionários, em agências maiores } \\
\text { devido a setorização ser grande.” } \\
\text { Q-6 “... toda relação tem aspectos positivos e negativos. Ao entrarmos numa } \\
\text { empresa tomamos conhecimento de suas normas, se não concordamos } \\
\text { temos a opção de sair. A empresa não vai conseguir agradar a todos.” } \\
\text { Q-7 “A empresa se dedica e valoriza os aspectos de RS.” } \\
\text { Q-8 “...na qualidade de vida, bem estar, maior disposição." } \\
\text { Q-9 “...sim, pelos alongamentos, ajuda a evitar LER/DORT.” } \\
\text { Q-12 "Não vejo benefícios reais.” } \\
\text { Q-13 "Por enquanto não vejo nenhum aspecto positivo, espero que tenha na } \\
\text { ascensão profissional.” }\end{array}$ \\
\hline $\begin{array}{l}\text { Aspectos } \\
\text { Negativos }\end{array}$ & $\begin{array}{l}\text { Q-4 “Sim, falta tempo na prática, como disse gostaria de ter mais tempo.” } \\
\text { Q-5 “Falta tempo.” } \\
\text { Q-10 “.... os valores para aprimoramento deveriam ser maiores." } \\
\text { Q-11 “... o único benefício real é a participação nos lucros (PLR)." } \\
\text { Q-12 “...falta tempo.” } \\
\text { Q-13 “São impostas ao funcionalismo, não há discussões.” } \\
\text { Q-16 “... não leva em conta as habilidades do funcionário. Só prioriza o } \\
\text { conhecimento. A pressão por metas, leva o funcionário a estresse e } \\
\text { conseqüentemente a problemas de saúde.” }\end{array}$ \\
\hline $\begin{array}{l}\text { Nível de } \\
\text { participação }\end{array}$ & $\begin{array}{l}\text { Q-1 "Pouca participação em QVT, mais em meio ambiente e desenvolvimento } \\
\text { de carreira nenhuma, não dá tempo". } \\
\text { Q-2 “Em programas de capacitação de funcionários e atividades de } \\
\text { prevenção... ginástica laboral e massagem". } \\
\text { Q-3 "Participo sempre”. } \\
\text { Q-4 "Participo moderadamente, não tenho tempo". } \\
\text { Q-5 “Eu participo das sessões de alongamento e massagem a medida do } \\
\text { possível, quando dá tempo". } \\
\text { Q-6 “...dentro da medida do possível procuro seguir o que é proposto". } \\
\text { Q-7 "Sempre que o banco ou a agência propõe... participo e me engajo, mas } \\
\text { vejo que a maioria dos funcionários não participa". } \\
\text { Q-9 "Participo dos alongamentos". } \\
\text { Q-10 "Participo de todos possíveis ao meu alcance (tempo)". } \\
\text { Q-11 "Moderada para pouca". } \\
\text { Q-12 "Quase nenhuma". } \\
\text { Q-15 "Procuro sempre que possível participar dessas ações, quando dá". } \\
\text { Q-16 "Procuro fazer as provas para a certificação, porém não me sinto } \\
\text { motivado a estudar". } \\
\text { Q-17 "Tento aproveitar os cursos realizados pelo banco para o meu } \\
\text { crescimento profissional”. }\end{array}$ \\
\hline
\end{tabular}

Quadro 5: Categoria 4 de análise

Fonte: Dados da pesquisa. 
Nesse momento da análise dos resultados se procurou evidenciar as opiniões relacionadas aos aspectos positivos e negativos, bem como 0 envolvimento e participação dos funcionários nas ações.

Em relação aos aspectos positivos novamente o discurso relacionado à qualidade de vida com as práticas de atividades laborais ficou entre a maioria das respostas. Um dos respondentes qualifica os benefícios em prol da própria empresa gerando uma maior rentabilidade devido à economia dos materiais de uso interno, devido à conscientização dos funcionários. Dois dos respondentes disseram não visualizar nenhum aspecto positivo na prática.

Quanto aos aspectos negativos poucos se manifestaram a respeito, sendo os comentários na maioria relativos à falta de tempo para a prática das ações. Um dos participantes evidenciou a imposição pela empresa das ações ao funcionário e outro fez uma crítica quanto a empresa não fazer referencia as habilidades naturais do funcionário e somente contar com o conhecimento adquirido por meio de treinamentos.

O envolvimento dos funcionários nas ações demonstrou ser pouco, ou nenhum, praticamente somente nas atividades de QVT evidencia-se alguma participação. Novamente os funcionários destacaram a falta de tempo para a prática.

A participação dos funcionários se limita em grande parte aos exercícios físicos e massagens relaxantes proporcionadas dentro do ambiente de trabalho. Evidencia-se o pouco uso das ações voltadas para a qualificação e aprimoramento profissional.

Ressalta-se a falta de tempo para adequar o cotidiano dos funcionários à possível pratica dessas ações, levando ao entendimento que as ações não atingem a efetividade. Percebe-se uma relação entre o fator tempo evidenciado pelos participantes, afetando a qualidade de vida das pessoas, tomando seu tempo livre, fora do expediente interno, para a sua qualificação. Também se percebe que a empresa quer que o funcionário se mantenha qualificado, pelo aspecto do programa de certificações internas, mas que pela opinião dos pesquisados, falta proporcionar a estrutura como material e condições adequadas para o estudo. 
Nesse aspecto ressalta-se a postura de Soares (2004), onde a autora menciona a não existência de condições reais que proporcionem ao trabalhador benefícios efetivos e ações que sejam verdadeiras.

\section{CATEGORIA 5}

5. "Falta tempo... a essência dos programas são boas, mas não são efetivos. Infelizmente o banco disponibiliza as ações, mas não o tempo, mais importante...sei também que depende de cada um".

Definição: Em relação a efetividade das práticas que a empresa propõe, os funcionários destacam a falta de tempo, a necessidade de envolvimento por parte do funcionalismo, dentre outros discursos apresentados.

\begin{tabular}{|c|c|}
\hline TEMA & Exemplos de Verbalizações \\
\hline $\begin{array}{l}\text { Efetividade das } \\
\text { ações e } \\
\text { coerência X o dia } \\
\text { a dia dos } \\
\text { funcionários }\end{array}$ & 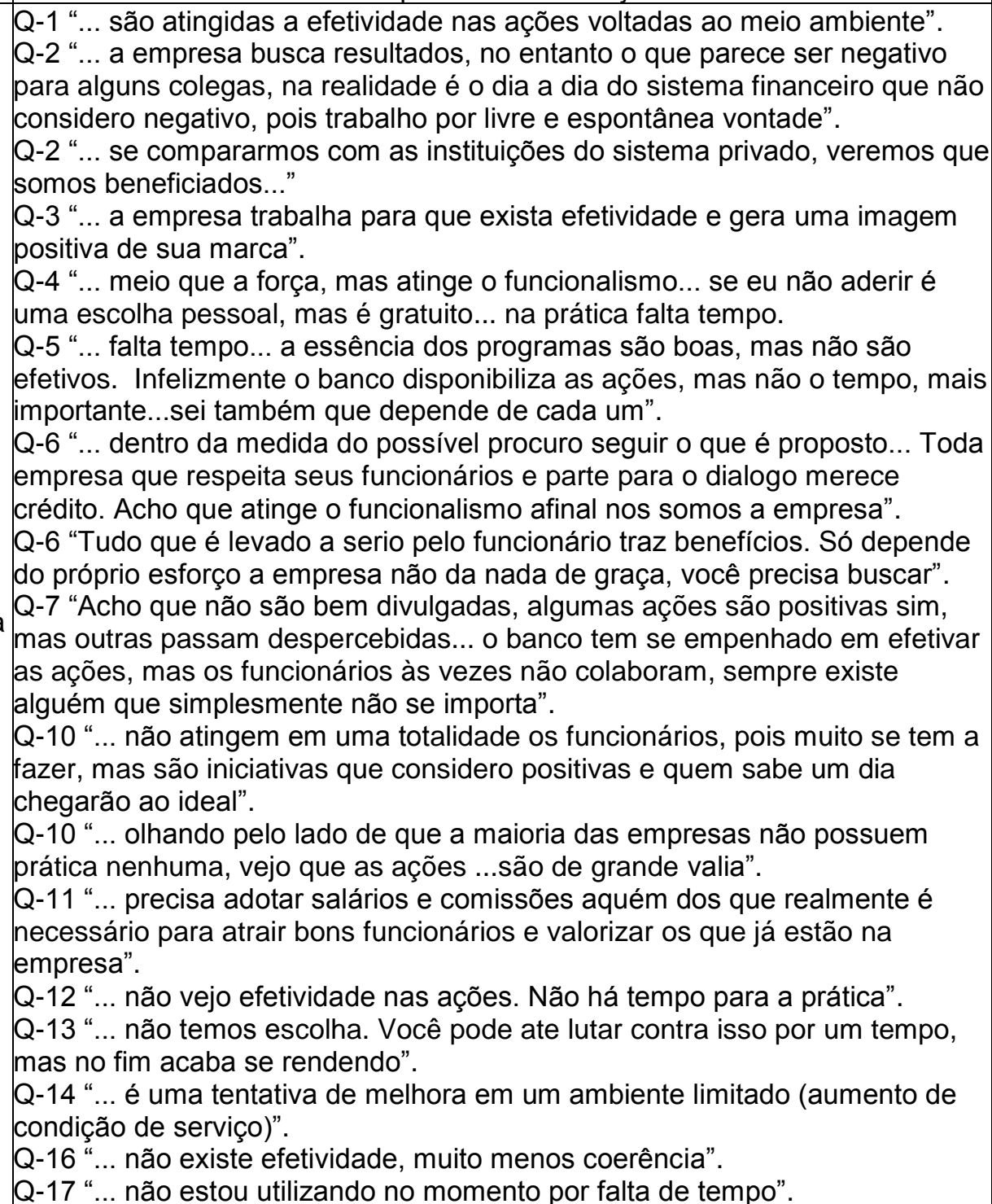 \\
\hline
\end{tabular}

Quadro 6: Categoria 5 de análise

Fonte: Dados da pesquisa. 
Nas verbalizações categorizadas, se procurou evidenciar a opinião dos participantes do estudo quanto à efetividade das ações propostas pela empresa e a coerência entre os discursos promovidos e a prática do dia a dia.

Essa categoria se relaciona com a segunda e terceira variável do estudo que induz ao conhecimento da viabilidade e aplicabilidade das ações propostas pela empresa.

As opiniões apontam para diferentes conotações. Dois dos respondentes estabelecem uma relação positiva se em comparação com as demais empresas e instituições privadas, apontando para a falta de práticas adotadas no meio empresarial.

O que nos leva a opinião de Ashley (2004), para a autora a RSC no Brasil ainda é um tema em desenvolvimento e ainda não existe nenhum grande feito que merecesse atenção honrosa, além do mais é preciso que os empresários percebam o que é RSC como um todo, adotando políticas e estratégias para todos os envolvidos.

A autora ainda faz um discurso informando que não existe como esperar atuações que tomem por referência práticas desenvolvidas em países de primeiro mundo, já que a cultura de cada país influencia no comportamento do meio empresarial.

Outros discursos encontrados nas verbalizações dos participantes apontam para a necessidade de envolvimento e dedicação do funcionário e que o dia a dia dos funcionários é a realidade do sistema financeiro como um todo.

Alguns evidenciam o fator tempo, já bastante mencionado nas categorizações dos aspectos negativos e na participação e envolvimento nas ações, como fator negativo, ou seja, a impossibilidade de conciliar as atividades do dia a dia com as propostas de RSC da empresa.

Em outro momento, se percebe verbalizações que conferem críticas quanto à imposição das ações ao corpo funcional, a falta ou pouca divulgação das propostas da empresa, a não existência de condições de trabalho tornando as propostas inviáveis à realidade do dia a dia, a pressão por metas levando o funcionário a problemas de saúde, ainda, apontam para que a empresa adote condições salariais e remuneratórias que sejam condizentes para obter funcionários qualificados. 
Nesse sentido, se percebe que os colaboradores da organização são uma fonte de recursos utilizada por essa e assim como os recursos naturais que precisam ser renovados e autossustentáveis, também o funcionalismo precisa se desenvolver e se aprimorar profissionalmente. Tendo condições de manter-se, crescer e ascender na sua carreira, além de manter uma qualidade de vida saudável.

As verbalizações aqui também encontradas se reforçam com as colocações de Soares (2004), que argumenta quanto ao capitalismo e o posicionamento das organizações frente aos seus objetivos. 


\section{CONCLUSÕES E RECOMENDAÇÕES}

O estudo apresentado teve como objetivo conhecer as opiniões dos colaboradores de uma instituição financeira nacional quanto às práticas de RSC desenvolvidas pela empresa no ambiente interno de trabalho, voltadas para o corpo funcional. Procurando evidenciar em um primeiro momento o conhecimento que os colaboradores possuem a respeito da RSC como um todo e logo após relacionar o discurso que a empresa promove com a efetividade e viabilidades das práticas no dia a dia.

De acordo com a literatura discutida ao longo desse trabalho as crises mundiais econômicas ocasionaram à queda do Estado como principal mantedor dos serviços de bem estar social, levando uma grande parcela da humanidade a privações, miséria, fome e desemprego. Ainda, a revolução industrial também fez um marco no contexto da RSC, onde o mundo globalizado avançou rapidamente quanto à tecnologia, contribuindo de uma forma para o aumento do desemprego e dos problemas sociais.

Nesse contexto as organizações passaram a ser pressionadas pelo governo e pela sociedade a assumirem sua parcela de responsabilidade junto aos seus envolvidos. Devolvendo parte dos recursos utilizados para sua expansão econômica, até então, a única preocupação por parte dos empresários.

Todos são afetados pelas mudanças globais, tanto a sociedade que começa a se ver ameaçada pela falta de estrutura do poder público em manter a ordem e a proteção às pessoas, como as próprias empresas passam a perceber a ausência de um corpo funcional que possa contribuir de fato para 0 desenvolvimento econômico do país.

Nos primórdios da RSC, em um primeiro momento as discussões se relacionam a quesitos básicos em benefício aos trabalhadores, como à regulamentação das condições de trabalho da classe operária, incluindo jornada de trabalho, assistência a saúde, controle do trabalho infantil, lazer e descanso semanal aos trabalhadores, entre outros.

Ainda na atualidade, muitas empresas utilizam de discursos relacionados às condições trabalhistas para estarem inseridas no contexto da 
RSC e obter uma imagem positiva perante a sociedade. Não é difícil perceber na mídia, propagandas de empresa que se intitulam pioneiras em determinada região, geradoras de emprego e renda, desenvolvendo economicamente seus estados e regiões, mas, como se conclui nesse estudo isso não é praticar RSC. Em outros casos desenvolvem um grande apelo de preservação dos recursos do meio ambiente e bem estar da sociedade, esse sendo o mais utilizado.

A partir dos anos 1990, após as pressões da sociedade, consumidores e da mídia, é que a RSC começa a ser discutida entre algumas organizações do país e passa a incorporar estratégias organizacionais. Observa-se então que as organizações passam a discursar sobre ética e ações voltadas para o benefício social em prol da construção de uma imagem sólida e positiva que trará ganhos econômicos as empresas. O que pela reflexão de alguns autores relacionados na literatura desse trabalho é um direito das empresas em aliar às práticas de RSC a um marketing positivo.

De modo que pode-se concluir que usada ou não como estratégia meramente corporativa, se tornam imprescindíveis os estudos e discussões que possam relacionar as promessas ao que realmente se faz e se alcança de efetivo, seja no meio dos trabalhadores, bem como junto a todos os grupos de envolvidos.

Nesse contexto, cresce o interesse do meio acadêmico na investigação e no conhecimento das discussões a cerca da RSC, mas, grande parte dos estudos se relaciona às ações voltadas a sociedade e ao meio ambiente, por uma constante inflamação na mídia. São poucos os estudos que procuram evidenciar a opinião dos trabalhadores quanto à coerência existente no discurso socialmente responsável das empresas e a prática de seu cotidiano. Momento no qual se percebe o vasto campo para estudos e pesquisas futuras, com o intuito de promover a disseminação do conhecimento a respeito do assunto, bem como por meio desses conscientizar todos os stakeholders envolvidos.

Na pesquisa aplicada nesse estudo ficou evidente uma conscientização por parte dos trabalhadores a respeito do que é a RSC e da responsabilidade existente por parte das empresas em atuar de maneira ética e social junto aos grupos de envolvidos. 
O resultado da pesquisa evidenciou que os participantes do estudo encontram-se inseridos no contexto da RSC, a percebem com diferentes olhares, ora voltado ao meio ambiente, ora para a sociedade e em muitos discursos para o seu próprio ambiente de trabalho. $O$ que corresponde às colocações de Parente (2006), as quais foram apresentadas no referencial teórico desse estudo, a respeito da crescente conscientização da sociedade e a cobrança quanto à responsabilidade presente nas ações das organizações para com todos os quais se relaciona.

Os resultados também demonstram, conforme evidenciamos na introdução do estudo, que as instituições financeiras têm trabalhado para criar uma imagem satisfatória perante seus públicos, o que nos remete ao resultado evidenciado quanto à percepção dos trabalhadores nas ações que a empresa promove para reduzir gastos com recursos naturais, criando uma imagem positiva.

O que é favorável, lembrando os comentários de Grabrielli (2008), que destaca os benefícios que a empresa pode auferir aliando as estratégias da empresa às práticas de RSC.

Ainda, a opinião dos participantes do estudo, revela a necessidade de que as empresas além de disponibilizar ações e práticas que possam proporcionar melhor qualidade de vida, ascensão na carreira e crescimento tanto pessoal quanto profissional, façam com que essas sejam palpáveis, acessíveis e principalmente reais e efetivas. Que possam perfazer o cotidiano de seus colaboradores e possam ser utilizadas de fato, já que a maioria destaca a falta de tempo para conciliar o dia a dia com as propostas da empresa.

Já nesse aspecto, o contexto vai de encontro com as colocações de Soares (2004) que ressalta a postura do capitalismo frente aos objetivos das organizações e que essas tomam uma postura que oculta o interesse de uma minoria, não dando condições verdadeiras ao trabalhador e nem assumindo qualquer compromisso que proporcione benefício real.

Na prática o que se pode observar é que existem muitos discursos a respeito por parte da empresa, mas, pouca comunicação e produtividade efetiva dessas ações junto ao corpo funcional. 
Em resumo, fica evidente a conscientização da sociedade com um todo e que essa tem o poder de cobrar dos responsáveis, ações que possam visar o beneficio comum e mais, o crescimento e o desenvolvimento autossustentável do país.

Nos discursos que levam a discussão da efetividade e coerência existente nas práticas que a empresa dispõe, conclui-se que muito se tem a fazer para que as mesmas atinjam de fato o funcionalismo, tendo como principal fator negativo a questão "tempo", que se percebe pela opinião dos trabalhadores na impossibilidade de conciliar o cotidiano com o que a empresa propõe.

De modo que pode-se concluir que não basta a qualquer organização fazer adesões a códigos regulamentadores, discursos e programas a respeito da RSC enquanto suas práticas não forem tangíveis e principalmente atingirem o objetivo ao qual se propõe.

Em síntese muito se tem a fazer no campo da RSC, tanto no aspecto que diz respeito a estudar e discutir exaustivamente o relacionamento que as empresas propõem para com todos os grupos de envolvidos. Bem como perceber por meio da opinião do ser humano, seja ele visto como sociedade ou trabalhador, qual a verdadeira efetividade dos discursos que são promovidos.

É importante que o meio acadêmico possa ser utilizado como uma ferramenta de conscientização da sociedade e dessa forma pressionar as organizações para visualizar o ser humano e a sociedade como eles de fato são e não como máquinas que são utilizadas e descartadas quando já não oferecem utilidade qualquer.

Pesquisas nesse campo de estudo tem a contribuir para a conscientização de administradores em geral, da sociedade, dos próprios colaboradores, alem de levar conhecimento a todos os interessados. Ainda pode-se inferir a contribuição para o meio acadêmico com futuros trabalhos. Quanto mais abrangentes forem os estudos relacionados e as discussões a respeito da RSC, maior será o envolvimento de todos os grupos envolvidos.

Ressalta-se ainda as limitações encontradas para aplicação da pesquisa, quanto aos questionários, a maioria dos participantes do estudo encontram dificuldade em participar da pesquisa, justificando a falta de tempo 
para que possam responder as questões, de modo que foram necessários vários contatos com o objetivo de conseguir o máximo de envolvidos possível.

O campo de estudo do presente trabalho limitou-se a evidenciar a opinião e conhecimento dos colaboradores, mas ressalta-se que esse é apenas um dos interessados e diretamente envolvidos, sendo vasto o campo para futuras pesquisas. A opinião de funcionários e colaboradores é essencial no momento em que traduz a realidade das práticas que as empresas se propõem, mas não é a única a ser observada. 


\section{REFERÊNCIAS}

ACEVEDO, Claudia Rosa; NOHARA, Jouliana Jordan. Monografia no curso de Administração. 3. Edição Revisada. São Paulo: Editora Atlas S.A., 2009.

ASHLEY, Patricia Almeida. Ética e Responsabilidade Social nos Negócios. 1. Edição. São Paulo, SP: Editora Saraiva, 2004.

BRANDÃO, Thales. Não acredite que os bancos no Brasil praticam Responsabilidade Social Empresarial. Cidade MKT, jan. 2011. Não paginado. Disponível em: http://www.cidademarketing.com.br/2009/ar/104/no-acrediteque-os-bancos-no-brasil-praticam-responsabilidade-social-empresarial.html>. Acesso em: 14 mar. 2011.

COSTA, Evandro Américo. Revisão da norma ABNT NBR 16001 Responsabilidade Social. CNC - Confederação Nacional do Comércio de Bens, Serviços e Turismo, abr/2011. Disponível em:

<http://www.cnc.org.br/central-do-conhecimento/trabalhos-tecnicos/revisao-danorma-abnt-nbr-16001-responsabilidade-social-a>. Acesso em: 05 mai. 2011.

CUNHA, Maria do Carmo Aguiar da. O que é Responsabilidade Social Empresarial?. Comunicação IETEC. Disponível em: $<$ http://www.techoje.com.br/site/techoje/categoria/detalhe_artigo/477>. Acesso em: 14 mar. 2011.

DRUCKER, Peter F. Uma era de descontinuidade - Orientações para uma Sociedade em Mudança. 3. Edição. Rio de Janeiro: ZAHAR EDITORES, 1976.

FROES, Francisco Paulo de Melo Neto Cesár. Responsabilidade Social \& Cidadania Empresarial - A Administração do Terceiro Setor. Rio de Janeiro, RJ: Qualitymark Ed., 1999.

Gestão da Sustentabilidade do Banco do Brasil. Disponível em: $<$ http://www.bb.com.br/portalbb/page4,8305,3912,0,0,1,6.bb?codigoNoticia=28 458\&codigoMenu=15217>. Acesso em: 11 abr. 2011.

GRABRIELLE, Juliana. Responsabilidade Social Corporativa: mais do que marketing ou mera filantropia, é estratégia de sustentabilidade. Junho, 2008. Disponível em: <http://www.administradores.com.br/informe- 
se/artigos/responsabilidade-social-corporativa-mais-do-que-marketing-ou-merafilantropia-e-estrategia-de-sustentabilidade/23271/>. Acesso em: 14 mar. 2011.

Herbert de Souza (Betinho). Publicado em 27 abr. 2009. Disponível em: <http://www.brasilcultura.com.br/sociologia/herbert-de-souza-betinho/> Acesso em: 05 mai. 2011.

Indicadores ETHOS de Responsabilidade Social Empresarial. Disponível em:

$<$ http://www.ethos.org.br/docs/conceitos_praticas/indicadores/temas/publico_int erno3.asp>. Acesso em: 30 mar. 2011.

INSTITUTO DE PESQUISA ECONÔMICA APLICADA - IPEA. Pesquisa sobre ação social nas empresas. Brasil - resultados finais - segunda edição 2006. Disponível em: <http://www.ipea.gov.br/acaosocial/inicio.html>. Acesso em: 30 mar. 2011.

Instituto ETHOS de Empresas e Responsabilidade Social - Empresas Associadas. Disponível em:

<http://www.ethos.org.br/sistemas/empresas_entidades/empresas_associadas/l ista_geral/index.asp.> Acesso em: 02 mai. 2011.

KARKOTLI, Gilson. Responsabilidade Social Empresarial. Petrópolis, RJ: Vozes, 2006.

KRAEMER, Maria Elisabeth Pereira. Responsabilidade Social Corporativa como estratégia para o desenvolvimento sustentável. Disponível em: <http://www.alfinal.com/brasil/ResponsabilidadeSocial.php >. Acesso em: 14 mar. 2011.

LIMA, Gilberto Barros.Gestão de Projetos Sociais. Comunicação IETEC. Disponível em:

<http://www.techoje.com.br/site/techoje/categoria/detalhe_artigo/49>. Acesso em: 14 mar. 2011.

MAXIMIANO, Antonio Cesar Amaru. Introdução à Administração. Edição Compacta, São Paulo, SP: Atlas Ed., 2006.

O que é RSE. Instituto ETHOS de Empresas e Responsabilidade Social. Disponível em:

<http://www1.ethos.org.br/EthosWeb/pt/29/o_que_e_rse/o_que_e_rse.aspx>. Acesso em: 27 abr. 2011. 
OLIVEIRA, José Augusto; ALVARENGA, Rafael Pazeto; NADAE, Jeniffer de; OLIVEIRA, Otávio José de. Responsabilidade socioambiental em Instituições Financeiras: Dificuldades e Perspectivas. Revista Cientifica Eletrônica de Administração, Ano IX, número 17, DEZ 2009. Disponível em: <http://www.revista.inf.br/adm17/pages/artigos/ART04-ANOIX-EDIC17DEZ2009.pdf>. Acesso em: 14 mar. 2011.

PARENTE, Juracy; GELMAN, Jacob Jacques. Varejo e Responsabilidade Social - Visão Estratégica e Práticas no Brasil. Porto Alegre: Bookman, 2006. 182 p.

HOFFMAN-CÂMARA, R. A Inserção da Análise de Conteúdo no Método Qualitativo de Pesquisa. 8 f. Ensaio (Disciplina de Análise de Conteúdo no Mestrado em Gestão Social e do Trabalho). Não publicado. Instituto de Psicologia, Universidade de Brasília, Brasília, 2006.

ROMAN, Artur. Responsabilidade Social das empresas: Um pouco de história e algumas reflexões. Revista FAE BUSINESS, número 9, set. 2004. Disponível em:

$<$ http://www.fae.edu/publicacoes/pdf/revista_fae_business/n9/11_rs_empresas. pdf>. Acesso em: 14 mar. 2011.

SANTOS, Maria Estela Araújo Ferreira. Representações sociais em Responsabilidade Social Corporativa: Imagens e substâncias refletidas pelo olhar dos trabalhadores. 2005. 181f. Dissertação (mestrado em administração) - Universidade Federal da Bahia - UFBA, Salvador, BA. Disponível em:

http://www.bibliotecadigital.ufba.br/tde_busca/arquivo.php?codArquivo=1060. Acesso em: 14 mar. 2011.

SILVA, Edna Lúcia da; MENEZES, Estera Muszkat. Metodologia da Pesquisa e elaboração de dissertação. 3. Ed. rev. Atualizada. Florianópolis, 2001. Disponível em: <http://projetos.inf.ufsc.br/arquivos/Metodologia\%20da\%20Pesquisa\%203a\%20 edicao.pdf>. Acesso em: 23 mai. 2011.

SOARES, Gianna Maria de Paula. Responsabilidade Social Corporativa: Por uma boa causa!?. Revista RAE-eletrônica, v.3, n.2, Art. 23, jul/dez 2004. Disponível em: <http:/WWW.rae.com.br/eletrônica/índex.cfm?FuseAction=Artigo\&ID=1666\&Se cao=FOR.ESTCRI\&Volume=3\&Numero\&Ano2004>. Acesso em: 14 mar. 2011. 
SOUZA, Washington José de. Responsabilidade Social Corporativa e terceiro setor. Apostila preparada para o curso de administração na modalidade a distância. 2008. Brasília: UnB, 2009. Disponível em: <http://uab.unb.br/admeadnorte/course/view.php?id=79>. Acesso em: 02 mai. 2011.

TREVISAN, Fernando Augusto. Balanço Social como instrumento de marketing. Revista RAE-eletrônica, Volume 1, Número 2, jul-dez/2002. Disponível em:

<http://www.rae.com.br/eletronica/index.cfm?FuseAction=Artigo\&ID=1465\&Sec $\mathrm{ao}=\mathrm{PWC} \&$ Volume $=1 \&$ Numero=2\&Ano=2002> . Acesso em: $14 \mathrm{mar} .2011$.

ZANELLA, Liane Carly Hermes. Metodologia da Pesquisa.

Florianopólis:SEad/UFSC, 2006, 144p. Apostila preparada para o curso de administração na modalidade a distância. Brasília: UnB, 2009. Disponível em: <http://uab.unb.br/admeadnorte/course/view.php?id=79>. Acesso em: 02 mai. 2011. 


\section{APÊNDICES}

Apêndice 1

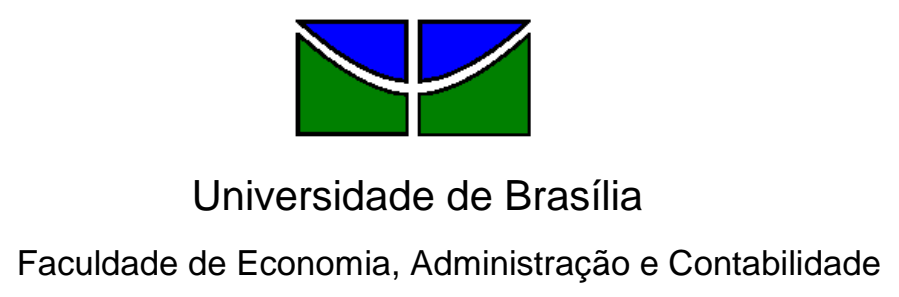

Caro(a) Senhor(a):

Necessito de sua ajuda para a construção dessa pesquisa. A necessidade da mesma se faz pelo fato da conclusão de curso superior, em que se espera a apresentação do trabalho de término de curso - TC.

Venho por meio desse questionário promover uma pesquisa que têm por finalidade diagnosticar qual a sua percepção em relação às práticas de responsabilidade social desenvolvidas por essa Instituição Financeira em seu ambiente interno, ou seja, as ações que são propostas exclusivamente para você funcionário. O objetivo da pesquisa é analisar a efetividade e aplicabilidade das ações que a empresa se propõe a desenvolver aos seus funcionários. Evidenciando os aspectos positivos e negativos.

Peço encarecidamente que responda o formulário em anexo. Não existem respostas corretas ou incorretas, apenas a sua opinião é de extrema importância para o resultado da pesquisa.

As respostas serão tratadas confidencialmente, não sendo necessária a sua identificação.

Desde já agradeço,

Ivone Maria de Souza

Aluna do curso de Administração 
Agência: Data da Pesquisa: /Jul/2011

Qual a sua idade e escolaridade?

Sexo: $F() M()$

Há quanto tempo trabalha na empresa? anos.

\section{Responsabilidade Social}

1. Comente com as suas palavras o que você entende por responsabilidade social corporativa.

\section{Responsabilidade Social X Funcionalismo}

1. Quais ações de responsabilidade social voltada aos funcionários você visualiza dentro do seu ambiente de trabalho?

2. Você consegue identificar ações voltadas para sua qualidade de vida? E para o seu desenvolvimento e crescimento profissional? Em caso positivo, cite quais são.

3. Você conhece a política da empresa quanto às práticas relacionadas às certificações internas para a ascensão profissional? Qual sua opinião a respeito disso? 
4. Qual sua participação nas ações que a empresa disponibiliza para você?

5. Você se sente beneficiado por essas ações? Há algum benefício nelas? Em caso positivo, cite quais são.

6. Há algum aspecto negativo em relação às práticas que a empresa adota? Quais são eles?

7. Há aspectos positivos em relação às práticas que a empresa adota? Quais são eles?

8. Qual a sua opinião a respeito da efetividade nessas ações, ou, elas realmente atingem o funcionalismo?

9. Você observa coerência entre o que a empresa se propõe e a prática do seu cotidiano? Comente sua resposta. 